\title{
Financial Stability Reports in Latin America and the Caribbean
}

\author{
Cheng Hoon Lim ${ }^{1}$ \\ International Monetary Fund, USA \\ CLim@imf.org \\ Alexander D. Klemm \\ International Monetary Fund, USA \\ AKlemm@imf.org \\ Sumiko Ogawa \\ International Monetary Fund, USA \\ SOgawa@imf.org \\ Marco Pani \\ International Monetary Fund, USA \\ MPani@imf.org \\ Claudio Visconti \\ International Monetary Fund, USA \\ CVisconti@imf.org
}

\begin{abstract}
Many countries in Latin America and the Caribbean now publish financial stability reports. They use FSRs as a tool for financial surveillance and communication. This study reviews their latest issues to assess their content, quality, and transparency, and the extent to which the country's macrofinancial and institutional context affect the quality of the publications. While some reports provide a strong analysis of risks and vulnerabilities, there are significant cross-country differences, and many reports could be improved by adopting a more comprehensive, forwardlooking, and thematic assessment of financial stability. A well thought out communication strategy, including a regular and predictable publication schedule and an easily accessible website, is also important to enhance the impact of the reports. Data gaps, particularly at the disaggregated level, are material and need to be urgently addressed.
\end{abstract}

JEL classification: G01; G18; G28.

Key words: Financial Stability Report; Financial Supervision.

1 Corresponding author. CLim@imf.org; Tel. +1-202-6237872; Fax +1-202-5897872. International Monetary Fund, 700 19th Street NW, Washington DC, 20431, USA. 


\section{INTRODUCTION}

Ensuring safe and healthy financial systems has become an important policy objective for policymakers around the world. While the real economy is dependent on credit intermediated by the financial sector to grow and innovate, the scale and speed of financial flows can overwhelm the real economy, especially in times of stress. From 1980 through 2007, the world's financial assets including equities, private and public debt, and bank deposits - nearly quadrupled in size relative to world gross product. ${ }^{2}$ A disruption to financial services could generate market volatility and, in a worst case, trigger a full-blown crisis that brings significant social and economic hardship to the population. The Great Recession that followed the 2008 upheaval in global financial markets, when the total value of the world's financial assets fell by a record $\$ 16$ trillion, ${ }^{3}$ is an important case in point.

An effective tool for communicating the health of the financial system and for presenting the policy toolkit available to address emerging risks is the publication of financial stability reports (FSRs). Publishing the assessment of financial stability on a regular basis alerts the general public (investors, savers, market analysts, and other observers) about potential and emerging risks and hold central banks and financial supervisors accountable for designing effective policy responses. By anticipating systemic risk and promoting a public debate about policies, FSRs would encourage more prudent behaviors and prompt the authorities to take actions that enhance financial system stability. Among the first countries to publish FSRs were the Bank of England and the Nordic central banks, whose countries had suffered a series of banking failures in the early 1990s. More recently, macroprudential authorities, including the U.K. Financial Policy Committee and the U.S. Financial Stability Oversight Council (FSOC) ${ }^{4}$ have assumed the responsibility for publishing FSRs in accordance to their new mandate to oversee systemic risk in the financial system. ${ }^{5}$

The purpose of this paper is to assess the extent which publication of FSRs have taken root in Latin America and the Caribbean (LAC) as a tool for financial surveillance and communication. The paper asks four questions: (i) who produces FSRs - the central bank or the macroprudential authorities, or a combination of both? (ii) how good is the content and quality of FSRs? This will be assessed against a defined set of benchmarks that covers the purpose and scope of the FSR, the data and analytical depth, and the communication strategy; and (iii) does the quality of an FSR depend on who issues it? and (iv) what are the FSRs' key strengths and areas for improvements? The paper will provide specific recommendations to improve the effectiveness and impact of FSRs.

Building on existing work, this study will review the content and quality of FSRs issued in Latin America and the Caribbean (LAC). There are two reasons why this is a timely exercise. First, the LAC region is undergoing significant financial deepening and development, and banks are becoming increasingly integrated across borders through financial conglomerate structures. With the region coping with slower growth and volatile capital flows as advanced economies continue to normalize monetary policy, it is important for central banks and regulatory authorities to closely monitor financial trends and emerging risks, and to develop a better understanding of the underlying structure of domestic and global financial markets. Second, the number of countries in the region issuing FSRs has now become sufficiently large to allow a comparative study of their quality and impact. Since 2002, when Brazil first published its FSR, the number

\footnotetext{
McKinsey \& Company, “Global capital markets: Entering a new era”, McKinsey Global Institute report, September 2009.

McKinsey \& Co. (2009).

The FSOC was established as part of the wholesale regulatory changes mandated by the Dodd-Frank Act. FSOC Annual Reports can be found on the FSOC website at https://www.treasury.gov/initiatives/fsoc/.

See “Country Reports”, Center for Financial Stability.
} 
has grown to 19 (Table 1). ${ }^{6}$ Given that the exercise is based on a subjective assessment relative to the established criteria, it will invariably involve an element of judgment.

The paper is organized as follows. Section 2 provides a brief literature review and the methodology that will be used in the assessment. Section 3 provides a brief description of the country sample, Section 4 reviews the types of institutions issuing the reposts, and Section 5 reports the results of the analysis, and discusses the correlation between the quality of FSRs with key macroeconomic and financial indicators. Section 6 concludes with specific recommendations to improve the quality and traction of FSRs.

\section{LITERATURE AND METHODOLOGY}

Studies that have attempted to assess the link between FSR publication and financial stability have indicated a positive relationship although the results are tentative at best. The first studies to make this attempt (Cihak (2006), Osterloo et al. (2007), and Cihak et al. (2012)) do not find a direct link between FSR publication and financial stability, although Cihak et al. (2012) conclude that "higher-quality reports tend to be associated with more stable financial environments."7 In another review, Wilkinson et al. (2010) find the FSRs of four advanced countries that have had considerable experience in preparing these reports (United Kingdom, Sweden, the Netherlands, and Spain) correctly identified the risks that contributed to the 2008 financial crisis in the period leading up to the crisis, but significantly underestimated their effects. The authors argue that had the FSRs fully anticipated the magnitudes of the potential problems, regulatory authorities and financial institutions might have taken more aggressive steps to mitigate the identified risk exposures. In their view, the challenge for policymakers going forward is to strengthen the surveillance role of FSRs with more rigorous and objective analysis. Born et al. (2014) analyze the impact of FSRs and other central bank communication on financial sector stock prices. They find that FSRs, especially when containing optimistic assessments, have a significantly positive impact on stock prices, highlighting the importance of FSRs as communication tools. Correa et al. (2017) construct a financial stability index based on positive and negative connotations of wording used in FSRs. They find that the sentiment captured in this index deteriorates just before the beginning of banking crises.

We apply the method developed by Cihak (2006) and illustrated in detail in Cihak et al. (2012). Under this approach, the quality of the reports is evaluated on the basis of 26 criteria covering five broad elements: clarity of aims (A), overall assessment (B), coverage of issues (C), data, assumptions, and tools (D), and structure and other features (E). For operational reasons, we have fleshed out the criteria in more detail than in the two Cihak studies but, to enhance the comparability with previous results, we have kept the same weighting and rating scale. While the details of the criteria are spelled out in the Appendix (Appendix Tables 1-2), the following gives an overview of the underlying principles.

\section{A: Aims, Objectives, and Reasons}

- FSRs should explicitly state their aims. The reports should aim to inform the public and encourage a constructive debate about financial sector developments and policies, holding public authorities accountable for their surveillance of the financial system. The information provided should facilitate a proper assessment of risks by investors active in the market.

\footnotetext{
6 In addition, the Caribbean Centre for Money and Finance (2016) at the University of the West Indies, in collaboration with the CARICOM central bank and banking supervisors, has recently published a Caribbean Regional Financial Stability Report. The report "complements the national financial stability reports and its purpose is to sensitize the main regional financial stability stakeholders, including the regional public, of issues relevant to the stability of the financial system in the region." This report is not assessed in this study.

The authors assessed the impact of FSRs on various indicators of financial stability (such as the occurrence of systemic banking crisis or indices of financial vulnerabilities) for 44 countries.
} 
- FSRs should be clear about what is meant by financial stability. The definition should include a dynamic perspective: a financial system is stable not only when it is carrying out its essential functions and services (such as providing payments and ensuring an efficient reallocation of funds from savers to investors), but when it is also capable of withstanding the shocks and strains that can be reasonably expected to affect it in the short and medium term. Since countries are exposed to different types of shocks, the definition can vary, to some extent, from country to country; it is however important that the report should clarify the operational benchmarks used to assess whether or not the system is stable, explaining what data, indicators, and type of information would be monitored for this purpose.

\section{B: Overall Assessment}

- The executive summary should be succinct and easy to read. The lack of a well-articulated executive summary is a missed opportunity to inform and guide public opinion. A reader should not have to sift through the entire report to distill the main conclusions of the analysis and should be able to understand the key messages of the report even if the reader is not financially sophisticated. More advanced and technical material should be covered in the analytical chapters, preferably in boxes or annexes. The function of the executive summary is to bring together the various strands of analysis developed in the rest of the report, presenting a panoramic and candid view of risks and vulnerabilities, including politically sensitive risks. The executive summary should also discuss how these risks have evolved since the previous issue of the report and provide a summary of the key recommendations.

- FSRs should integrate macroeconomic and financial analysis. This analysis should flow in both directions, assessing the key macroeconomic trends that can have an impact on the stability of the financial sector as well as the key financial sector developments that can, in turn, have an impact on the real economy. The report should identify the main transmission channels that link the financial and real economy and assess in quantitative terms how shocks in one area could reverberate in the other areas.

\section{C: Coverage of Issues}

- FSRs should be forward looking, frank, and consistent over time. This is the most important criterion and is often found lacking. The reports should not only describe past and current developments but look ahead to identify future trends that could bring both opportunities and risks to the financial sector. FSRs should not refrain from highlighting potential weaknesses or vulnerabilities, nor from addressing sensitive issues, while paying due regard to protecting confidentiality and avoiding unwarranted destabilizing comments. To facilitate clarity and comparisons, reports should also maintain a consistent approach over time, following up on topics raised in previous issues while they remain relevant; changes can be introduced occasionally, but they should be well motivated and clearly explained to the readers.

- FSRs should cover all relevant areas of the financial sector. While banks typically account for the largest share of the financial sector (e.g., in terms of assets or value-added), the reports should not limit the discussion to banks, especially if the nonbank financial sector and capital markets are significant by size or pose their own challenges. All these areas are potential sources of risk and vulnerabilities that could spread to other areas of the financial sector and also affect the real economy.

\section{D: Data, Assumptions, and Tools}

- FSRs should not only explain, but also properly justify the assumptions used. This is especially relevant in the case of stress tests, whose meaning and interpretation depends critically on the assumptions made regarding the severity of the shocks, the speed and scale 
of the impact of shocks on default probabilities, the hurdle rates on capital and liquidity, dividend distribution, and other parameters of the test. Ideally, stress tests should be computed within a general equilibrium framework with the support of satellite econometric models that link macroeconomic and financial conditions. Simpler, partial-equilibrium, or even ad hoc tests can also be appropriate, and could be the inevitable consequence of capacity or data constraints, but any limitations of this choice should be described and explained.

- FSRs should indicate the data and methodology used and make them easily available. As most reports already do, the sources and cut-off date of the data should be indicated clearly and in an easily identifiable place (in the introduction or preface of the report). The data used should also be made available to the public on the internet, in the same website where the reports are published. The methodology used for projections, sensitivity analyses, and stress tests should be explained in clear and simple terms in the text, with more technical details provided in special boxes or annexes. In analyzing the data, the report should consider not only aggregate and average measures but also distributional indicators and, where appropriate, extreme or individual values (with proper safeguards to preserve confidentiality), highlighting, for instance, the position of the weakest or most vulnerable institutions or asset classes.

\section{E: Structure and other features}

- The reports should follow a logical and integrated structure with unifying themes centered on the key risks. The structure should enable the reader to identify which parts of the report contain specific information about different topics, while also facilitating the discussion of cross-cutting topics. The structure should be consistent over time to allow the reader to compare the assessments and should contain boxes or appendices dedicated to issues that either evolve slowly over time (such as financial inclusion) or reflect passing concerns (such as "taper tantrum" capital flows). The reports should have an executive summary, several chapters devoted to external and domestic developments that affect the financial sector and changes in the financial infrastructure, including on the regulatory and supervisory framework, and should preferably include a table of acronyms, a glossary of technical terms, a methodological annex, and a statistical appendix.

- The publication of the reports should be supported by a well-designed communication strategy. The current and past issues of the reports should be made available on the internet in a dedicated webpage that is easy to navigate and easy to find on the home page of the publishing authority; this page should also contain a database containing the data used as well as links to other relevant publications and to other agencies and sources of information. The launch of the report should be supported by an outreach campaign aimed at disseminating the main messages and recommendations through audio-visual broadcasts, press releases, public presentations, and press conferences. The format and medium of the communication should be adapted depending on the intended audience.

- The publication of the report should follow a timely, regular and predictable schedule. As financial sector conditions can change very rapidly, reports should be published within three months of the cutoff date for the data, preferably at least two times a year. The publication date should be announced in advance, so that the readers know when to expect the next issue; and should change only infrequently. The past publication dates should also be clearly indicated on the website, to enable the readers to know what information was available to the public at different times.

To illustrate how this method is used to assess the quality of an FSR, we apply it to the July 2016 issue of the Bank of England's FSR as a demonstration of a report that meets these criteria effectively (Box 1). Nevertheless, this example should be put in context given that the United Kingdom has a much deeper financial system and the Bank of England has access to extensive 
technical and professional resources, the institutional mandate, and historical experience, that are not available to all the authorities that issue FSRs in the LAC region.

Each report is given a score between 1 and 4 (higher values representing better quality) on each of the 26 criteria. ${ }^{8}$ An overall composite score is computed as the weighted average of the ratings for all criteria, using the weights suggested in Cihak (2006) to maintain comparability. ${ }^{9}$ While the criteria and weights are the same for all countries, allowing a comparable assessment, this does not mean that a one-size fits all approach is taken. While some criteria clearly apply equally to all countries (e.g., the statement of aims), others are interpreted based on countryspecific factors. For example, when assessing whether all relevant risks are covered, comparisons were made with respect to country-specific risks and not a common set of global risk factors.

\section{Box 1. The Financial Stability Report of the Bank of England}

The Bank of England (BoE) has been one of the first central banks to publish FSRs, with the first report issued as early as $1996 .{ }^{1}$ Given its long history, the BoE has over the years honed the report to what is today considered an industry best practice. The key features of the July 2016 report include:

- A clear statement of aims and objectives. The FSR sets out the Financial Policy Committee's views of the outlook for financial stability, including its assessment of the resilience of the U.K. financial system and the current main risks to financial stability, and the action the Committee is taking to remove or reduce these risks. It also reports on the activities of the Committee over the reporting period and on the extent to which the previous policy actions have succeeded in meeting the Committee's objectives.

- A succinct executive summary. The Executive Summary pulls together the assessment under a single theme (in this issue, risks around the Brexit referendum) as the most significant nearterm domestic risks to financial stability.

- A candid assessment. The report clearly flags the challenging outlook for U.K. financial stability, noting the United Kingdom's large current account deficit, the over-stretched commercial real estate market, the high level of household indebtedness, subdued growth in the global economy, and fragilities in financial market functioning, are channels through which the referendum could increase risks to financial stability. The report identifies the policy actions that have been taken so far and makes clear that as the outlook evolves, the Financial Policy Committee stands ready to take any further actions deemed appropriate to support financial stability.

- An easy-to-follow structure that facilitates comparison over time. The report is divided into two parts (risks and resilience), with annexes that highlight previous macroprudential policy decisions and core indicators underpinning the countercyclical capital buffer and sectoral capital requirements.

- A full-fledged communication strategy. The BoE maintains a dedicated webpage on financial stability that is easily accessible from its home page and contains the latest and past issues of the FSR (since 1996), links to data and relevant studies, and an e-mail address for providing questions and feedback. The report is launched by the Governor with a press conference whose video recording and transcript are also available on the web page. The publication schedule is fairly regular, with past and next-issue publication dates clearly indicated on the webpage.

- Well documented data sources. While the report uses mainly aggregate data, it provides distributional analysis of key variables (such as capital) among banks. The cutoff date for the data is clearly indicated (July 1, 2016) and data corrections are also posted subsequently. Data for charts and tables used in the report are made available online, and a detailed description of the data used are provided in a series of footnotes.

Prior to 2006, the reports were known as "Financial Stability Review."

Each FSR undergoes several rounds of reviews. The final scores are determined after multiple iterations to ensure consistent application of the criteria.

9 We have also tested the robustness of the results to different weights by applying equal weights to all elements. These changes do not alter the substance of the results. 


\section{DATA AND SAMPLE}

The sample consists of the 20 latest FSRs issued by 19 countries in the region as of July 2016 (Appendix Table 3). In addition to the main sample of reports, we have also examined preceding reports, notably to asses those criteria that are about consistency (A3, A4, B3, C2, E3). These reports are available online. ${ }^{10}$ Among the Caribbean economies, four produce FSRs, a remarkable number considering the small size of these economies. However, three countries appear to have either delayed or discontinued their publication in the last few years (Ecuador, Guatemala, and Nicaragua). ${ }^{11}$

The 19 countries in the sample form a heterogeneous group, with per-capita GDP ranging from less than US\$2,000 (Nicaragua) to more than US\$20,000 (The Bahamas), population ranging from less than 300,000 (Barbados) to more than 200 million (Brazil), and GDP ranging from US $\$ 4.4$ billion dollars (Barbados) to more than US\$1 trillion (Brazil and Mexico) (Table 1). The three largest countries in the group (Brazil, Mexico, and Argentina) account for two-thirds of its population and GDP.

Table 1

Economic and Social Indicators of Sample Countries (as of end-2015)

\begin{tabular}{|c|c|c|c|}
\hline Country & GDP(US\$ billion) & Population (million) & GDP per capita (US\$) \\
\hline Argentina & 585.6 & 43.1 & 13,589 \\
\hline Barbados & 4.4 & 0.3 & 15,774 \\
\hline Bolivia & 33.2 & 11.5 & 2,886 \\
\hline Brazil & $1,772.6$ & 204.5 & 8,670 \\
\hline Chile & 240.2 & 18.0 & 13,341 \\
\hline Colombia & 293.2 & 48.2 & 6,084 \\
\hline Ecuador & 98.8 & 16.3 & 6,071 \\
\hline El Salvador & 25.8 & 6.4 & 4,040 \\
\hline Guatemala & 63.9 & 16.3 & 3,929 \\
\hline Honduras & 20.3 & 8.4 & 2,407 \\
\hline Jamaica & 13.9 & 2.8 & 4,948 \\
\hline Mexico & $1,144.3$ & 127.0 & 9,009 \\
\hline Nicaragua & 12.2 & 6.3 & 1,949 \\
\hline Panama & 52.1 & 4.0 & 13,013 \\
\hline Paraguay & 28.1 & 7.0 & 4,010 \\
\hline Peru & 192.1 & 31.9 & 6,021 \\
\hline The Bahamas & 8.7 & 0.4 & 23,903 \\
\hline Trinidad and Tobago & 24.6 & 1.4 & 18,086 \\
\hline Uruguay & 53.8 & 3.4 & 15,748 \\
\hline Sample Total & $4,668.0$ & 557.1 & ... \\
\hline Sample Average & 245.7 & 29.3 & 8,380 \\
\hline LATAC Region & $5,052.5$ & 615.8 & 8,205 \\
\hline Sample Total in percent of LATAC Region & 92.4 & 90.5 & $\ldots$ \\
\hline
\end{tabular}

Source: WEO (April 2016).

10 Some information about the readers of these reports can be gleaned from some partial download statistics provided by eight country authorities in the sample. Among the set of reports for which download data are available, each report has been downloaded on average 1,600 times. The number of downloads varies significantly across countries and time, frequently exceeding 10,000 in Brazil and rarely exceeding 1000 in smaller economies. Most downloads seem to come from domestic users: the local language versions tend to be downloaded more frequently than the English versions, and - when this information is available - most downloads appear to be made to domestic IP addresses (a high number of downloads from foreign IP addresses has been observed, however, in Trinidad and Tobago).

11 As of October 2018, Nicaragua has reinstated the publication of FSRs, with the 2017 report available online. 
The group also includes three countries with significant offshore financial activities (Barbados, Panama, and The Bahamas), eight highly dollarized economies, with a significant share of bank deposits and/or loans denominated in foreign currencies (Figure 1), and three fully dollarized economies (Ecuador, El Salvador, and Panama) that use the U.S. dollar as legal tender.

\section{Figure 1}

Foreign Currency Loans and Deposits (percent; end-2015)

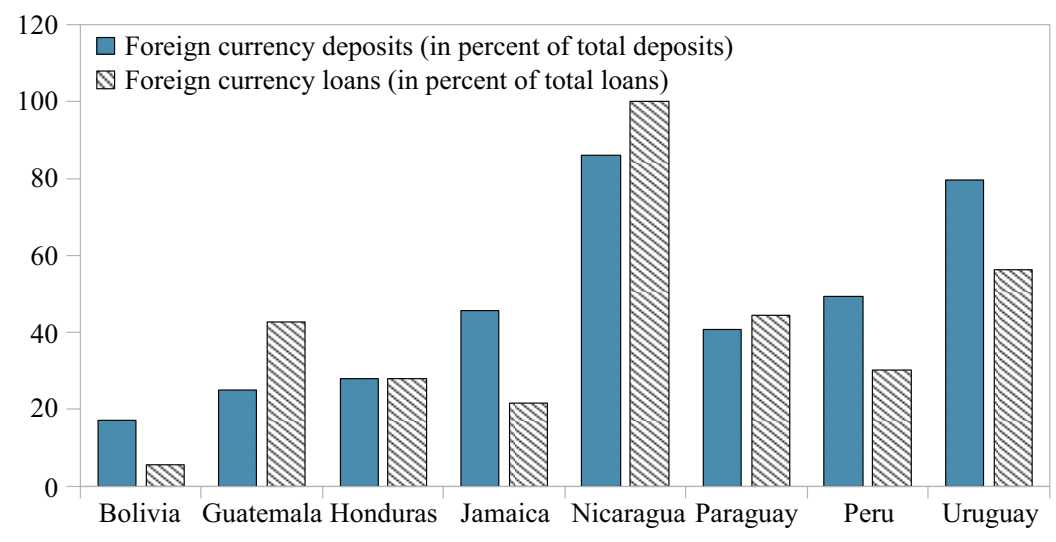

Sources: Monetary and Financial Statistics Database (MFS); country authorities; and authors' estimates.

The size and structure of the financial sector also varies widely among these countries (Figure 2). Measured by the sum of total banking assets, stock market capitalization, and bond issuance, ${ }^{12}$ Brazil has the largest financial sector in the region (US\$5.7 trillion), followed by Mexico (US\$1.6 trillion) and Chile (US $\$ 0.8$ trillion), also reflected in the depth of their capital markets and the significant presence of foreign investment. Chile has the largest financial sector in proportion to the size of the economy (more than three times its GDP), followed by Brazil and by the three offshore centers. Among the other countries, Colombia, Argentina, and Peru have a comparatively large financial sector (with total assets between US\$200 and US $\$ 600$ billion), and in Peru, Bolivia, Honduras, and Uruguay broad money and private sector credit exceed 40 percent of GDP; in the other countries the financial sector is much smaller.

\section{Figure 2}

Size and Structure of the Financial Sector (average 2010-15; percent of GDP) $)^{13}$

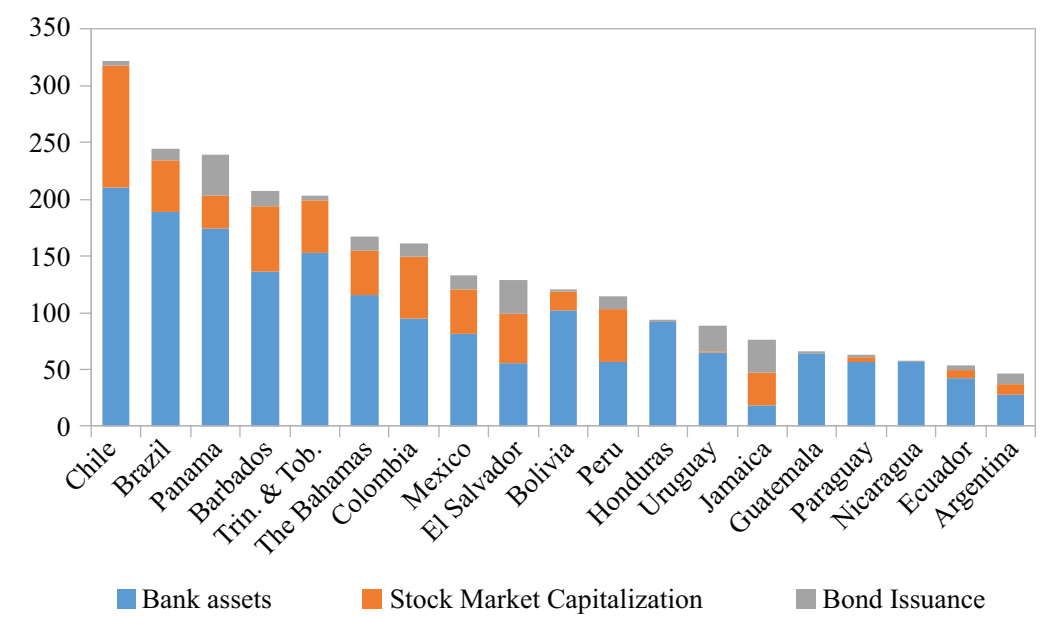

Sources: WEO; IMF VESD database; IMF Monetary and Financial Statistics database; World Federation of Exchanges; and authors' estimates.

12 Average data for the period 2010-15; data compiled by IMF staff on the basis of information provided by country authorities and market data.

13 Sum of total banking assets, stock market capitalization, and outstanding bonds issuance. 
The number of banks (including credit unions, cooperative, and microfinance institutions) ranges from less than 20 (in Nicaragua and Uruguay) to more than 100 (in Mexico, Peru, Trinidad and Tobago) and more than 1,000 in Brazil. ${ }^{14}$ Countries also differ markedly in terms of financial sector penetration. The number of branches of commercial banks (arguably a more significant indicator of financial inclusion in geographically large countries with a large population than it is in smaller states) ranges from 5.3 per 100,000 inhabitants in Jamaica to 253 in Colombia; it is comparatively high in Brazil, Ecuador, Guatemala, and the Bahamas, but relatively low in the other countries (less than 25 per 100,000 inhabitants).

\section{WHO ISSSUES FSRS?}

Countries in the region tend to share financial stability oversight across different agencies. Of the sample countries reviewed in the paper, roughly 37 percent have institutional arrangements of financial stability that involve multiple authorities within a jurisdiction, with Mexico having as many as four agencies (Table 2). The authorities typically include the central bank, a committee within or outside the central bank, the bank supervisory agency, or another authority such as the deposit insurance agency. In fact, the 2018 IMF Macroprudential Policy Survey indicated that unlike other regions where central banks play strong roles, the LAC region had the lowest percentage of jurisdictions reporting the central bank as one of the macroprudential authorities.

Table 2

Latin America and the Caribbean: Financial Stability Reports

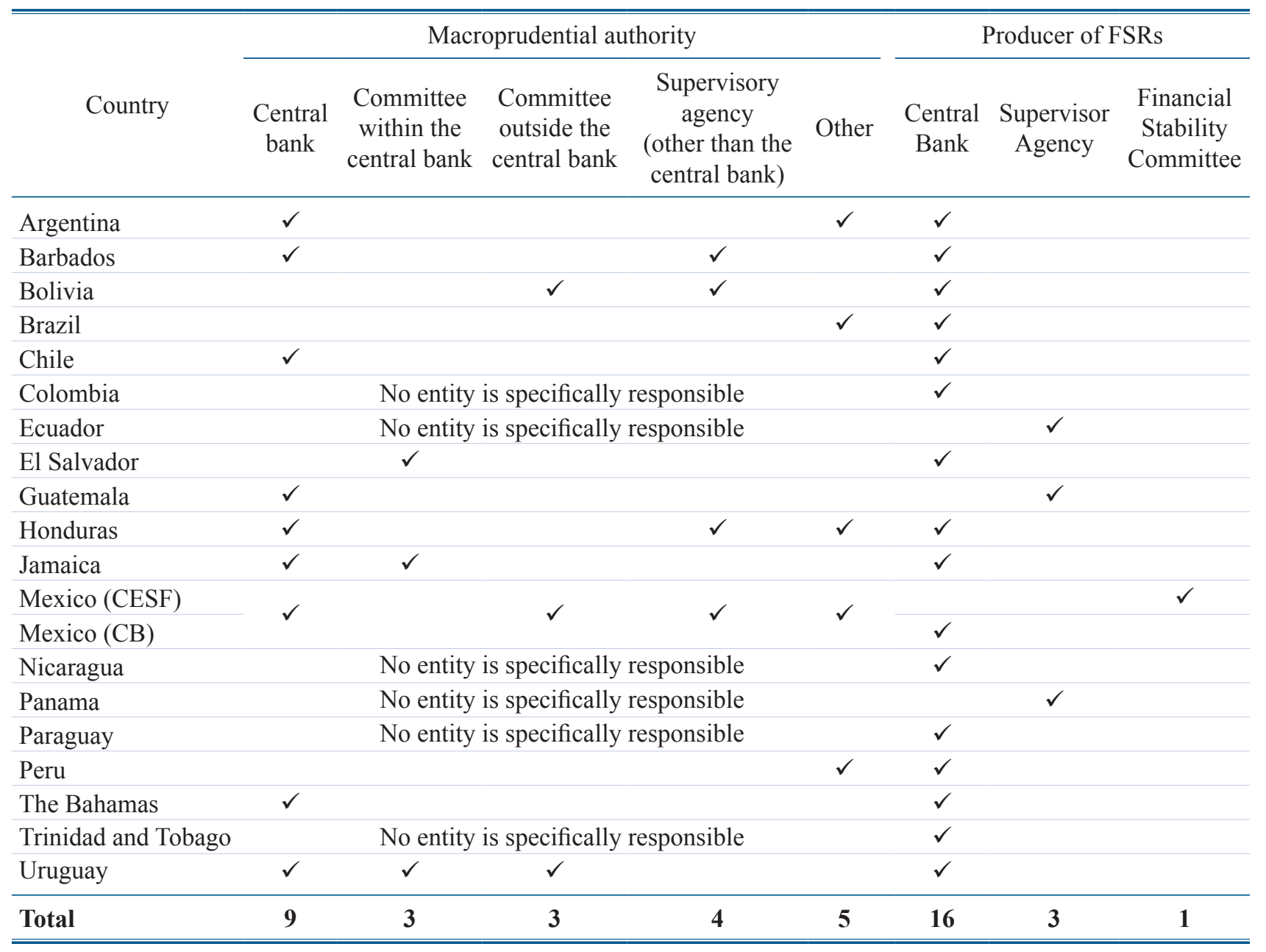

Source: Central bank and other authorities' websites; IMF Macroprudential policies Survey. In Mexico, two FSRs are published, one by the Central Bank, "Mexico (CB)," and one by the Financial System Stability Council (CESF), "Mexico (CESF)."

14 FAS data for 2014. 
Despite the institutional arrangements for macroprudential policy, FSRs from the region are predominantly issued by central banks. The exceptions are Ecuador, Guatemala, Panama and Mexico. In Mexico, both the central bank and CESF, the other agency responsible for financial stability, publish FSRs: both FSRs are reviewed in this study (Box 2). Given the existing institutional arrangements, collaboration between the central bank and the macroprudential authorities would be important to ensure that there is clarity and transparency about financial stability issues, accountability for policies, as well as a strategy for communicating emerging risks and vulnerabilities.

\section{Box 2. Financial Stability Reports in Mexico}

Mexico is the only country in this sample where two FSRs are published by two different institutions.

- The Bank of Mexico has published a "Financial System Report" since 2006. It is published annually in the fall.

- The Council for Stability of the Financial System (CESF) has published an annual report on financial stability and the Council's activities every spring since 2011. The CESF, which was created in 2010, is chaired by the Ministry of Finance and includes representatives from the Bank of Mexico, the financial supervisory authorities (bank, insurance, and pension supervisors), and the deposit insurance authority.

\section{Box Figure 1}

Mexico: Comparison of FSRs

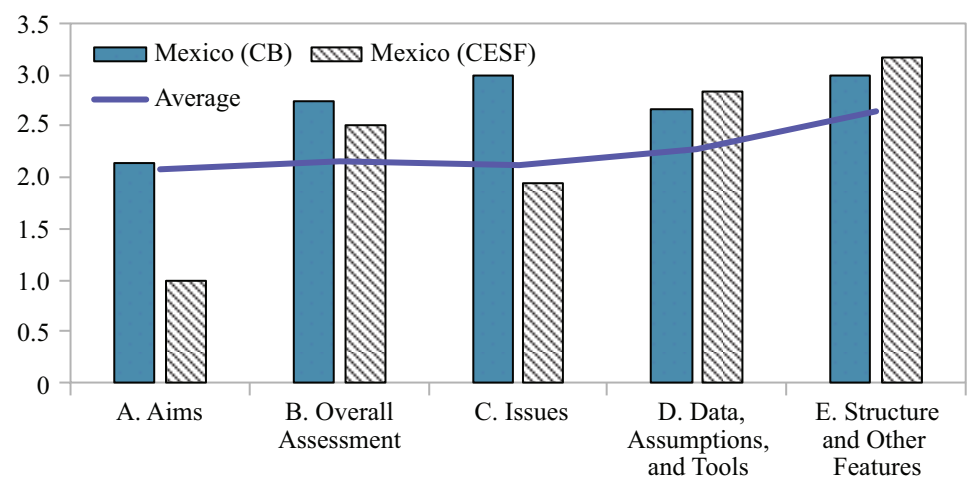

Source: Authors' Estimates.

Despite the different names, both reports cover financial stability issues and publish similar stress tests. Based on the evaluation criteria used in this study, the report by the Bank of Mexico (Mexico (CB)) is overall stronger. In particular, the Bank of Mexico report clearly spells out its aims and has a more comprehensive coverage, including banks, investment funds, insurance companies, households, and non-financial corporations while the CESF report focuses on banks. The CESF report provides a better justification of the assumptions underlying stress tests and has maintained a more consistent structure (the structure of the Bank of Mexico's report was changed without explanation in 2015). In other categories, the quality of the two reports are similar although neither provides a definition of financial stability. Both reports provide a strong overall assessment (Bank of Mexico with the added advantage of a risk map), identifying clearly the main macro-financial risks confronting the Mexican economy.

The 2016 FSAP has recommended making the CESF the main forum for communicating stability assessments. Simply moving to a single report without other institutional changes could, however, have some drawbacks. In particular, the Bank of Mexico is an independent institution, and should be able to express its views on financial stability. The CESF, on the other hand, is chaired by the Ministry of Finance, and all its members apart from the Bank of Mexico are run by boards that include representatives from the Ministry of Finance. Unless financial supervisors become more independent - as also recommended by the FSAP - abolishing the Bank of Mexico report would remove an important independent assessment of financial stability. 


\section{RESULTS}

The average overall composite score for the entire sample of 20 FSRs is $2.23^{15}$ (out of a maximum of 4); no report rises above 3, and three-quarters lie below 2.6 (Table 8). This score is broadly in line with the average comprehensive rating ${ }^{16}$ for emerging market economies assessed by Cihak et al. (2012), which is 2.24 (Figure 3), lower than the average for advanced economies (3.04) but higher than that of low income countries (1.67. These data are, however, only partly comparable, not only because they refer to different periods, but also because the criteria used are based on a subjective assessment that includes a degree of judgment. nevertheless, the broadly similar score among emerging market economies suggests that as a group, these economies face the same challenges in publishing financial stability assessments.

Figure 3

Average Composite Scores of FSRs (score scale from 1 to $4 ; 4=$ full compliance)

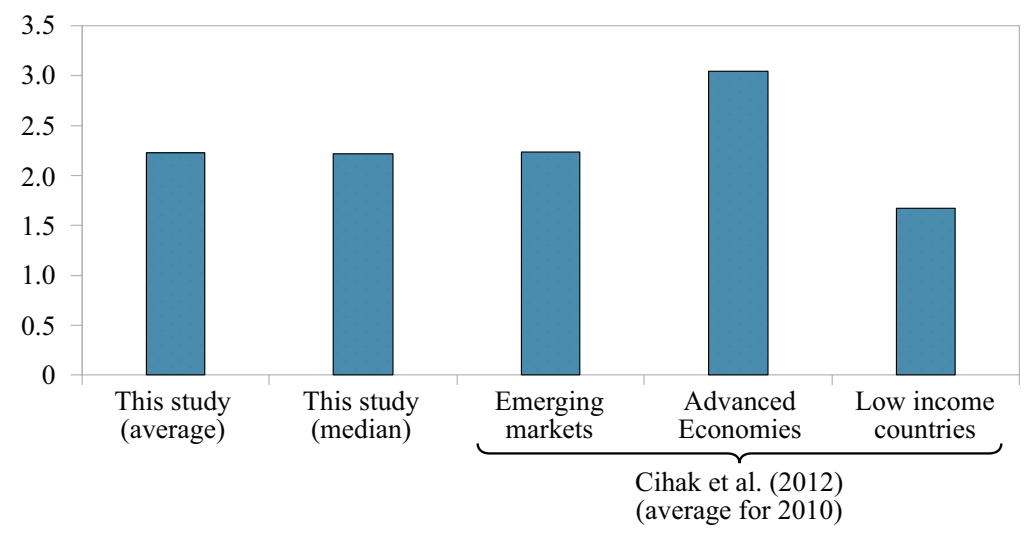

Source: Authors' assessment

The overall composite score, however, masks significant differences across countries (Table 3; Figure 4). The top group includes the six best reports (Brazil, Chile, Colombia, Jamaica, Mexico (CB) and Trinidad and Tobago), with overall scores between 2.5 and 3. The middle group includes seven reports (Argentina, Barbados, Bolivia, Honduras, Mexico-CESF, Paraguay, and Peru) that obtained an overall score between 2 and 2.5; and the bottom group includes seven reports (Ecuador, El Salvador, Guatemala, Nicaragua, Panama, The Bahamas, and Uruguay) that obtained an overall score below 2 (but higher than 1.5).

Table 3

Quality Rating of FSRs (Comprehensive and by Element): Summary Statistics

\begin{tabular}{llllccl}
\hline \hline & Mean & Min & Max & Lower Quartile & Upper Quartile & Weight \\
\hline Overall & 2.22 & 1.58 & 3 & 1.86 & 2.6 & 1 \\
A & 2.09 & 1 & 3.71 & 1.11 & 2.96 & 0.21 \\
B & 2.15 & 1 & 3 & 2 & 2.69 & 0.2 \\
C & 2.11 & 1.35 & 3 & 1.71 & 2.35 & 0.17 \\
D & 2.27 & 1.33 & 3 & 1.83 & 2.63 & 0.3 \\
E & 2.65 & 1.67 & 3.33 & 2.33 & 3 & 0.12 \\
\hline \hline
\end{tabular}

Sources: Authors' estimates.

15 The median value is equivalent at 2.22. If equal weights are used for all elements, the average score increases to 2.25 .

16 In the Cihak et al. papers, the average overall score is called the "comprehensive rating." The sample in the paper included only four countries in Latin America, with an average overall score of 2.04; the same countries in this study have an average overall score of 2.61. This would reflect - within the limits of comparability between these two assessments - some positive effects from learning-by-doing for these four countries. 


\section{Figure 4}

Composite Scores of FSRs by Country (score scale from 1 to $4 ; 4=$ full compliance)

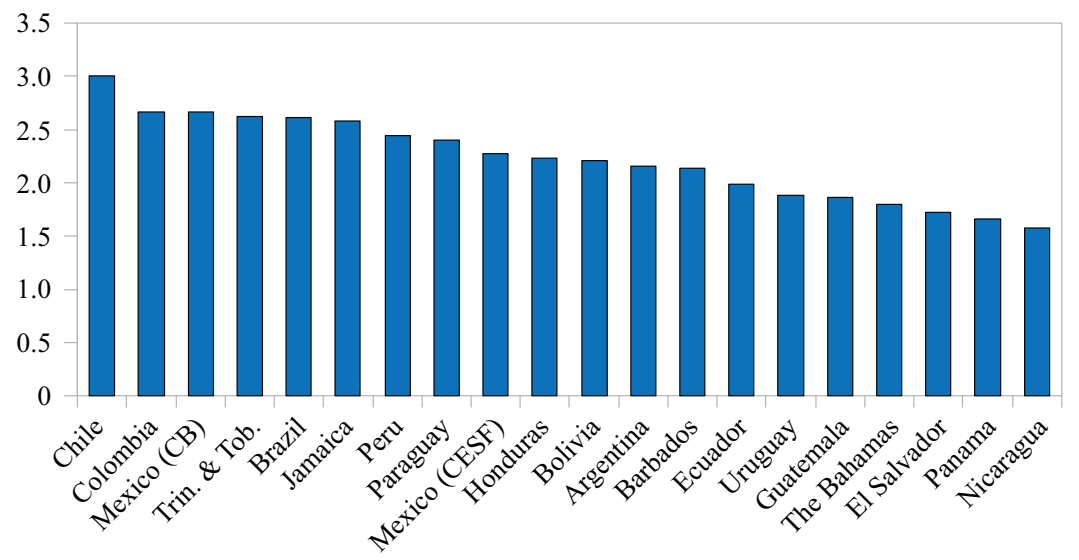

Source: Authors' assessment.

In addition, the reports that score a higher rating on one element tend to be better also on the others. In particular, performance on elements B, C, D, and E (overall assessment, coverage of issues, use of data and tools, structure) is correlated across reports, while scores along A are more independent (Table 4). Among these elements, the FSRs score lowest in A, B and C, suggesting these reports could state more clearly their objectives and improve the quality of their overall assessment and their coverage of issues. In general, countries do better at getting the structure and other logistical features of the report right than in providing more in-depth analytical content.

Table 4

Correlation between Country Scores of Different Elements

\begin{tabular}{llllll}
\hline & A & B & C & D & E \\
\hline A & 1 & & & & \\
B & -0.09 & 1 & & & \\
C & 0.16 & 0.63 & 1 & 1 & 1 \\
D & 0.26 & 0.4 & 0.52 & 0.51 & 1 \\
E & 0.39 & 0.38 & 0.4 & & \\
\hline \hline
\end{tabular}

Sources: Authors' estimates.

That being said, the region is not unique in facing challenges in communicating financial stability issues. The average score of the FSRs in the region is comparable to the estimates obtained by Cihak et al. (2012) for the group of emerging market economies. Breaking down by element, despite the lack of clarity in defining the objectives of the FSRs, the region still does better in this area (A) compared to other emerging economies. But the quality of their overall assessment (B) and coverage of issues (C) is still weak by comparison (Figure 5). 
Figure 5

Average Composite Scores by Region (score scale from 1 to 4; 4 = full compliance)

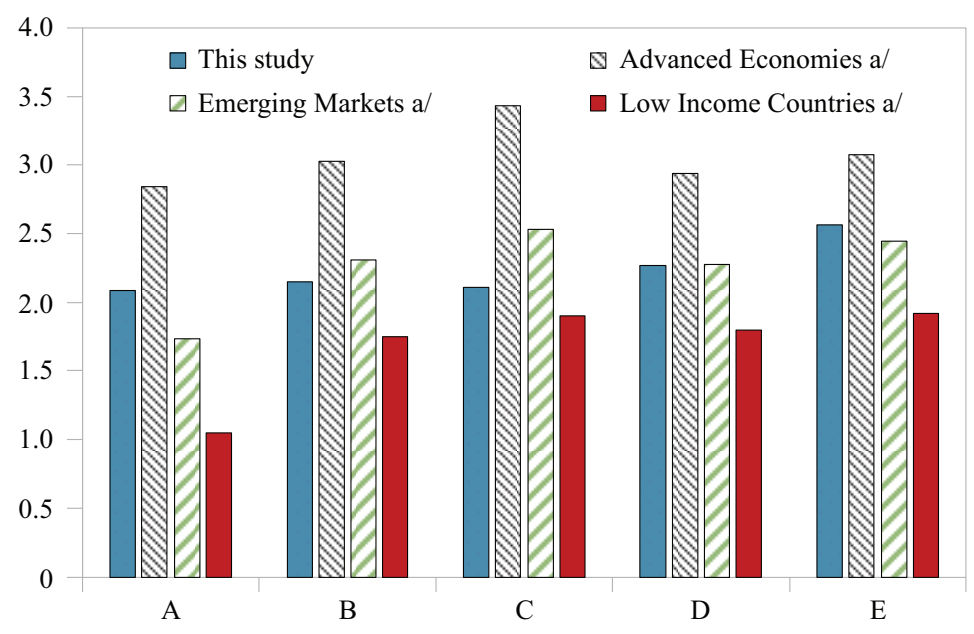

Sources: Authors' assessment; and Cihak (2012); data for 2010.

\subsection{Detailed Results}

\subsubsection{Element A: Reasons, Aims, and Objectives of the Reports}

An effective communication of the authorities' assessment of the conditions and resilience of the financial system requires clarity about the aims of the analysis and how the authorities define financial stability. To this purpose, each FSR should contain, at the beginning and in a conspicuous place (e.g., preface or introduction), an explicit statement of its aims and a clear definition of financial stability: "clarifying the definition of financial stability helps the reader understand the FSR's statement on financial stability." (Cihak et al., 2012) Any changes in the aims of the report should be clearly explained and justified.

The definition of financial stability should cover both the absence of a crisis and resilience to systemic shocks. ${ }^{17}$ This distinction is important, as a financial system that is highly vulnerable to shocks or fragile ${ }^{18}$ cannot be considered stable; a stable financial system must be capable of withstanding normal sized-shocks to which it is exposed and in mitigating the impact if a crisis were to occur. Typically, countries use a range of indicators, information, and methods as operational targets to guide the actual implementation of the strategy, for instance, ensuring a well-capitalized and liquid banking system, imposing large exposure limits to mitigate contagion risk, maintaining an efficient and well-functioning payment system, running regular stress tests, providing a lenderof-last-resort facility, and promoting a strong supervisory culture and regulatory framework.

What should FSRs aim for? While the ultimate purpose is to improve the stability and efficiency of the financial system, the more proximate aims of the report should include (i) informing stakeholders about new trends in financial markets and their potential benefits and risks; (ii) encouraging an informed debate on issues concerning financial stability, (iii) making the authorities accountable for the policies and actions they take to enhance resilience and mitigate risks; and (iv) provide information that can be used by participants in the financial sector to assess risks and make informed decisions.

Of the 20 reports analyzed in this study, only 9 explicitly state their aims, usually in the preface or in the introduction; 8 do not contain any statement of aims; some of these contain a brief description of their content, which is not sufficient because it does not describe the function of the report; other reports provide a statement of the mandate and objectives of the authority that issued

Financial crisis is defined as an event in which substantial losses at financial institutions and/or their failure cause, or threaten to cause, serious dislocations to the real economy. See Borio and Drehmann (2009).

18 A financial system is said to be fragile if normal-sized shocks are sufficient to produce a financial crisis. 
them, which is also not fully satisfactory because it does not explain what the authorities intend to achieve, specifically, by issuing the report (Figure 6, A1); and in two cases, the aims of the report are described on the central bank website, but not in the report itself, and may thus be missed by a reader who does not review, or have access to, the website.

\title{
Figure 6
}

Element A: Distribution of Scores (score scale from 1 to $4 ; 4$ = full compliance)

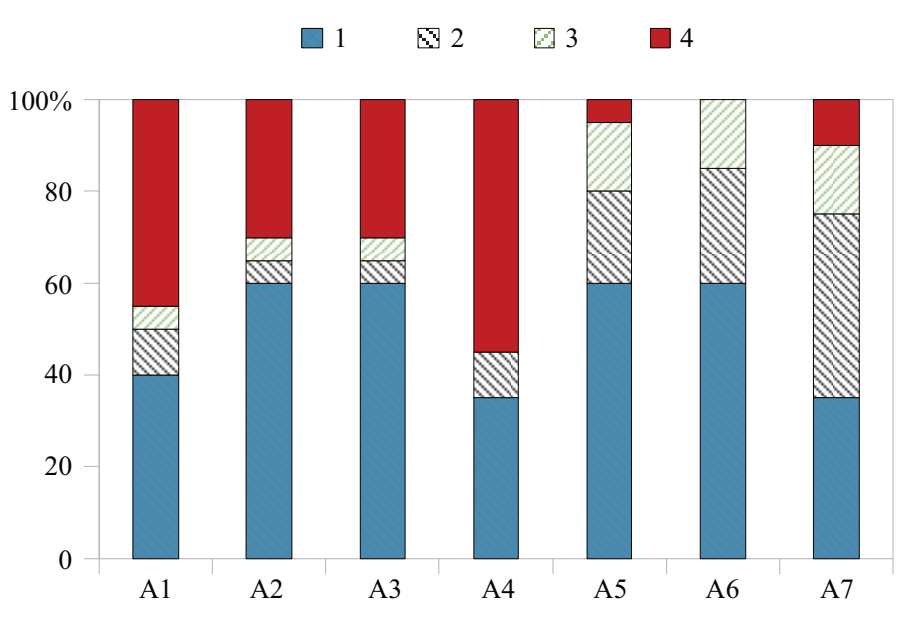

Sources: Authors' assessment.

The reports that obtained a high overall score usually include an explicit statement of their aims. Several reports stand out (e.g. Argentina, Chile) in describing their aims:

\begin{abstract}
"Provid[ing] information... on recent macroeconomic and financial events that could affect the financial stability of the Chilean economy. In addition, the Report presents the policies and measures that support the normal operation of the internal and external payment system, with the objective of promoting general knowledge and public debate with regard to the Bank's performance in fulfilling this function (emphasis added).
\end{abstract}

the [Central Bank of Argentina] communicates its vision of the state of the financial system, the initiatives aimed at its development, and its assessment of its stability. In the FSR, the [Central Bank] pays special attention to identifying and analyzing any systemic risks and to explain the action it takes to prevent or mitigate them. This publication helps the different actors make their decisions with more and better information, facilitating a proper management of their activities. The FSR is thus an instrument to stimulate the debate over issues related to financial stability and, in particular, over the action of the [Central Bank] in this area" (our translation; emphasis added)."

The majority of the reports (12 out of 20) do not provide a definition of financial stability, and those that do, provide a generic definition relating to the financial sector's role to intermediate funds and promote an efficient allocation of resources from savers to investors. In one case, the definition is posted elsewhere on the website, and in another buried in the glossary of the report (Figure 6, A2). Only two reports define financial stability in sufficiently detailed static and dynamic terms (absence of a crisis and resilience; Figure 6, A5), although - like the other reports - they tend to avoid using the word "crisis," perhaps out of concern that focusing the readers' attention on severe tail events could in and of itself be destabilizing.

None of the reports includes a clear operational definition of financial stability (Figure 6, A6). However, in two reports (Colombia and Jamaica) reference to the mandate of the central bank provide some operational guidance on how financial stability is conceived from an operational perspective: 


\begin{abstract}
"The tasks that the (Colombia) Bank of the Republic performs with a view to promoting financial stability are as follows: first, the Bank is responsible for ensuring the proper functioning of the payment system used in the Colombia economy; second, as the issuer of currency it provides for the liquidity of the financial system through its monetary operations and by exercising its constitutional authority as lender of last resort; third, the Bank, together with the Financial Supervision Authority of Colombia, in its capacity as a lending authority contributes to the design of financial regulatory mechanisms that reduce the incidence of instability episodes; finally, the Bank of the Republic performs careful monitoring of economic trends that could jeopardize financial stability.
\end{abstract}

The (Jamaica) central bank's mandate to maintain financial stability entails "making sure that financial institutions, in particularly banks, are sound... overseeing the efficient and smooth determination of asset prices, making certain that participants are able to honor their promises to settle market transactions and preventing the emergence of systemic settlement risk arising from financial imbalances that may develop within individual institutions in the system."

There is consistency over time in how reports define their aims and definition of financial stability (Figure 6, A4). Reports that state their aims in the latest issues have also included it in their previous issues (the converse is also true: reports who do not state their aims in the latest issues usually have not stated them in previous issues either). Similarly, the definition of financial stability is generally provided (or omitted) consistently over time and is usually found (where it is available) in the same place in different issues (Figure 6, A3).

\title{
5.1.2. Element B: Overall Assessment
}

To convey effectively the authorities' assessment of financial stability and policy messages, FSRs should provide a clear and candid overall assessment of the situation in an executive summary. A well-articulated executive summary requires strong analysis and a comprehensive coverage of issues in the rest of the report. The executive summary should discuss all significant risks and vulnerabilities, including politically sensitive risks, pointing out the main macro-financial transmission channels and how risk exposures have evolved over time. In this perspective, the overall assessment provided in the executive summary should have a forward-looking lens: it should anticipate new threats, identify possible trigger points, and discuss the likelihood and impact of negative shocks. Finally, the executive summary should be succinct and written in an easy-to-digest manner. This would allow the FSRs to reach a wider audience, beyond the financially sophisticated readers to the "man or woman on the street".

With two exceptions, ${ }^{19}$ all the reports examined in this study provide an overall assessment in the form of an executive summary, a preface/introduction or, in one case, a concluding chapter. The quality of these assessments varies considerably (Figure 7). In some reports the assessment covers key financial sector developments and their implications for financial stability, as well as a discussion of specific risks. For example:

- Chile's report notes that while existing capital levels are sufficient to absorb shocks under a severe stress scenario, capital buffers have been reduced over time;

- In Mexico (CB) the executive summary brings together the various pieces of analysis developed in the rest of the report to present a comprehensive view of potential risks and vulnerabilities;

- Trinidad and Tobago's report identifies specific risks related to persistently low oil prices, a sharp house price correction, sovereign debt restructuring in the Caribbean, and a spike in US interest rates.

19 Argentina and Panama. 
Figure 7

Element B: Distribution of Scores (score scale from 1 to $4 ; 4=$ full compliance)

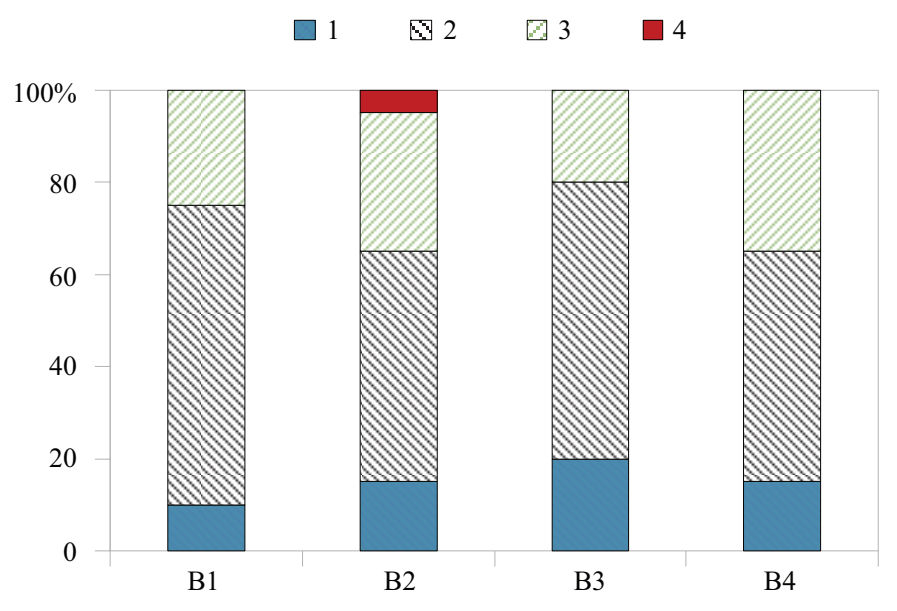

Sources: Authors' assessment.

In other reports the discussion of risks is more limited and presents statistics and trends based on financial ratios and indicators without a deep analysis of the underlying causes and implications, and with a stronger focus on describing historical developments than on drawing inferences for the future.

Nevertheless, even in the best reports in the sample, the overall assessment tends to be descriptive rather than analytical (describing recent developments in key variables and indicators without delving into the causes of these developments, their economic significance, and potential implications), ${ }^{20}$ backward rather than forward looking. Stress tests are used to support generic statements about the adequacy of liquidity and capital in the banking system, without much elaboration of the underlying context, scenarios, assumptions, and risks (Box 3). They often come across as a "box checking" exercise, done as a matter of routine, rather than as a well thought out framework to assess the financial system's resilience in the face of potential shocks and the authorities' preparedness to respond with contingent policy actions. Few reports make an attempt to connect their assessments over time, following up on previous statements and risks and explaining what changes had occurred in the intervening period.

\subsubsection{Element C: Coverage of issues}

FSRs should identify clearly the most pressing financial stability issues, extending the coverage as necessary to the main players and stakeholders in the system, the main asset classes, and the channels of transmission between the "real" economy and the financial system, and adequate follow through with consistent analysis of these issues over time. Any lack of coverage in key areas (e.g., non-bank financial institutions, households and corporate sector, payment systems, regulatory changes) should be explained and justified. For example, if the payment system is covered in a separate report, a reference to this should be provided.

\footnotetext{
20 For instance, the overall assessment may provide quantitative details on the recent evolution of financial variables such as total bank assets, the stock of various categories of deposits, credit to households and enterprises, as well as nonperforming loans, interest rates, and some key indicators such as the capital adequacy ratio; the latest change in these variables may also be compared with their behavior in the previous period. In many reports, however, this information is provided without much analysis of the underlying causes and trends, a discussion of its implications for financial stability, or even a longer historical perspective (for instance, comparing these values with the record of the previous ten years or with specific benchmarks such as the period preceding the most acute crisis).
} 


\section{Box 3. Stress Tests}

The vast majority of FSRs routinely include stress tests or sensitivity analyses, but the coverage, methodology, and presentation of stress tests differ widely across reports.

- The coverage is often limited to the impact of credit risk on bank capital. Three FSRs (Jamaica, Nicaragua, and Paraguay) also cover nonbanks, such as securities dealers or financial companies. In addition to credit risk, some FSRs also cover exchange rate, interest, and liquidity risks.

- Some FSRs derive scenarios from macroeconomic or other concrete risks, while others appear to make ad hoc assumptions, for example, by simply assuming shocks to bank variables (such as the value of assets or losses on NPLs).

- The assumptions and methodology are generally explained but rarely justified. Few reports provide adequate justifications for scenarios and parameters. Some relate them to historical values (e.g., standard deviations), but even those would benefit from a discussion of current risks relative to history. Only one report relates assumptions explicitly to risks highlighted elsewhere in the report.

- Most reports devote either a chapter or a specific section to stress tests. In some reports, technical methodological aspects are described in a specific annex or box. The presentation may include detailed charts and discussions, overview tables, or just succinct qualitative statements (e.g., generic statements such as "no bank would fail to meet minimum capital requirements"). Some reports helpfully provide results of past stress tests along with the latest ones.

Justifying the underlying assumptions and choosing the most relevant risks and sectors leads to more effective stress tests. To achieve full integration into the FSR, the stress tests should address the risks highlighted elsewhere in the report or explain, how those risks are reflected in the stress scenarios. Depending on the available resources, the link between macroeconomic shocks and financial variables could be modelled or just explained, but unfortunately some reports just present unjustified ad hoc shocks. While past experience can provide useful guidance (e.g., in terms of distribution, correlation, and extreme value range), the analysis should be justified based on forward-looking discussions of risks, explaining why past values remain relevant. The coverage should depend on the structure of the financial sector (nonbanks should be covered where important), and tests should look beyond solvency and also examine the impact on liquidity and profitability. The results of the tests should be discussed extensively, both in qualitative terms (i.e., their implications for the stability of the financial sector and the appropriate policy response) and in quantitative terms (supported by tables and charts).

Stress tests often appears to be used for the affirmation of resilience, but stress tests could be used for more policy-relevant purposes. While some reports speak of tests being "passed," this will be a function of the assumed size of shocks. More relevant could be an interpretation of findings to spell out which business models, which types of shocks, and which types of asset structures lead to the highest vulnerabilities. This would allow supervisors and institutions to consider possible measures to increase resilience, even if the shocks do not lead to any breach in requirements.

Coverage of issues is by far the weakest area identified in the FSRs (Figure 8). Many reports omit important financial stability risks and do not integrate well the macroeconomic and financial analysis. More specifically,

- All reports avoid politically sensitive issues, which may reflect the preference of the central bank or supervisory agency to maintain arms-length from the government, but, in some cases, 
this approach weakens their effectiveness at identifying and communicating political risk that may have major implications for financial stability. ${ }^{21}$

- When risks are flagged, most reports do not discuss their relative importance in terms of their likelihood or impact.

- Macro-financial integration is limited to a cursory discussion of the effects of macroeconomic shocks (e.g., growth, exchange rate) on the financial sector, but rarely considers the feedback loop from the financial sector to the macroeconomy. For example, rapid private credit growth and concentration of exposures to real estate, and dollarization are relevant in several countries, but these issues and their potential feedback loops are not explored in any depth.

- Important issues raised in one report are not followed up in subsequent editions and readers are left wondering whether the exposure to these risks remains significant.

- Some reports focus on the banking sector and cover only marginally, if at all, other important areas of the financial sector such as insurance and pension funds, which are taking on more risks as they search for yield in a low interest rate environment.

- The treatment of financial infrastructure, which includes the payments system, trade clearing and settlement systems, risk management systems of market participants, and the regulatory oversight system, is patchy, with some reports providing good information and others largely ignoring this potential source of risk.

- Global financial spillovers can also have a significant effect on financial stability, and while the larger economies acknowledge and discuss these risks, others do not focus on the challenges in managing volatile capital flows.

\section{Figure 8}

Element C: Distribution of Scores (score scale from 1 to $4 ; 4$ = full compliance)

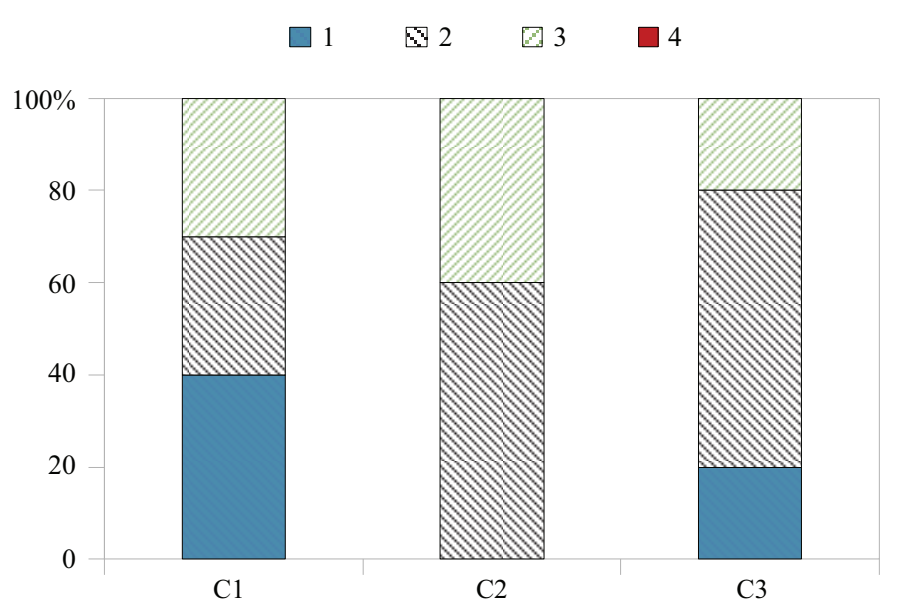

Sources: Authors' assessment.

Reluctance to engage in a frank discussion of sensitive issues and potential risks may stem from a variety of reasons, including fear that an overtly candid discussion could precipitate a crisis, while emphasizing risks that do not eventually materialize, could hurt reputations.

21 For instance, risks posed by "Operation Car Wash", a corruption scandal involving the state-owned oil company and top government officials that emerged in 2014 in Brazil, was discussed in a box in the October 2015 report, which used a contagion model to conclude that the financial system would be able to withstand the impact of the shock. However, there was no detailed follow-up in the subsequent report (only statements that the risk was being monitored) even though the scandal generated major economic uncertainty, weakened the currency, contributed to the recession, and eventually led to the impeachment of the President. Argentina's report for the second half of 2015, published only a few weeks before the elections that marked a major change in government, did not mention any potential spillovers to financial markets of uncertainty about the electoral outcome. 
Country authorities may prefer to err on the side of caution and not raise frequent alarms that over time may become uninformative "noise". Furthermore, country authorities whose institutional mandate is neutral and nonpartisan may refrain from tackling politically sensitive issues to avoid accusations of partiality or undue interference in the political process.

\subsubsection{Element D: Data, Assumptions, and Tools}

FSRs should use appropriate models and analytical tools as well as the full range of available data to enrich the analysis and facilitate comparison across time. A forward-looking assessment of risks should be based on a combination of quantitative and qualitative tools and any data gaps that detract from the assessment should be identified. Stress tests are recommended, but other methods based on well-justified assumptions and macro scenario can also be appropriate.

Most FSRs do indicate data sources and provide a cut-off date, but only a few make the data available electronically online (e.g. Brazil, Chile and Colombia) (Figure 9). Most reports also refer to aggregate developments, rarely venturing beyond a breakdown of results by broad categories of banks or using disaggregated data to analyze macro-financial interconnectedness. No report identifies data gaps even though they are important in several countries, thus missing the opportunity to acknowledge the risk of "unknown unknowns". Most reports use some form of quantitative tools, ranging from basic balance sheet analysis to sophisticated stress tests, but reports could adopt a wider set of qualitative tools, such as discussions on the quality of supervision or the integrity of the regulatory framework, including whether the crisis management framework is equipped to resolve a failed systemically important domestic bank.

Figure 9

Element D: Distribution of Scores (score scale from 1 to $4 ; 4=$ full compliance)

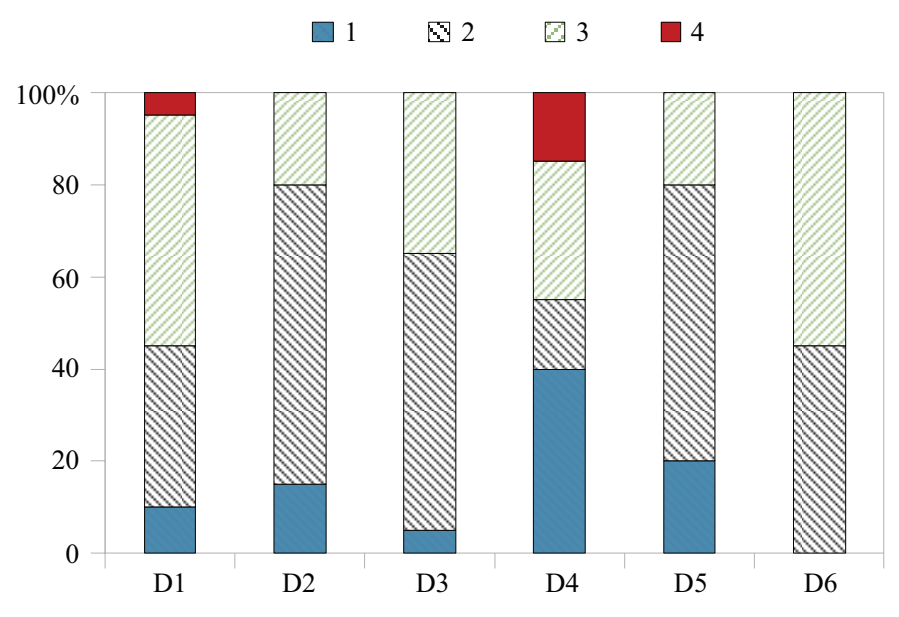

Sources: Authors' assessment.

Most reports do not justify their methodology or model assumptions or do so in very general terms. In a few reports, the analytical content is limited to a description of recent developments, such as the change in the non-performing loan ratio, without explaining the reasons behind the change, leaving the reader wondering about its relevance and severity. In a few other cases, the reports use methodologies that are not particularly suitable for the purpose of the analysis, either because the relevant data are not available or ad hoc adjustments are made to the methodology (e.g., in one case the stress test model is a reverse stress test that identifies the maximum shock that would leave the capital level above the hurdle rate without discussing the probability that a shock of this size or bigger could materialize). 


\subsubsection{Element E: Structure and Other Features of the Reports}

How a report is organized - in other words, its structure - can have a significant impact on its effectiveness. A good report should have a logical structure that is consistent over time to make it easier for repeat users to follow, but also flexible enough to allow for a unifying theme to run through the report. When the structure changes, the reasons should be explained. Other features of the report, such as its length, frequency, publication schedule, timeliness, and availability of past publications, all contribute to its effectiveness.

All the reports reviewed in this study follow logical and consistent structures, but they tend to adopt a "silo" rather than a thematic approach (Figure 10, E1 and E5). A typical report has a chapter on international and domestic macroeconomic developments, chapters on key segments of the financial sector, users of credit, payment system and regulatory framework. While this structure allows for a detailed discussion of each area of interest, it does not pull the disparate chapters together under an overarching theme. Some reports make a partial attempt through thematic boxes and annexes highlighting relevant cross-cutting issues. ${ }^{22}$

Figure 10

Element E: Distribution of Scores (score scale from 1 to $4 ; 4=$ full compliance)

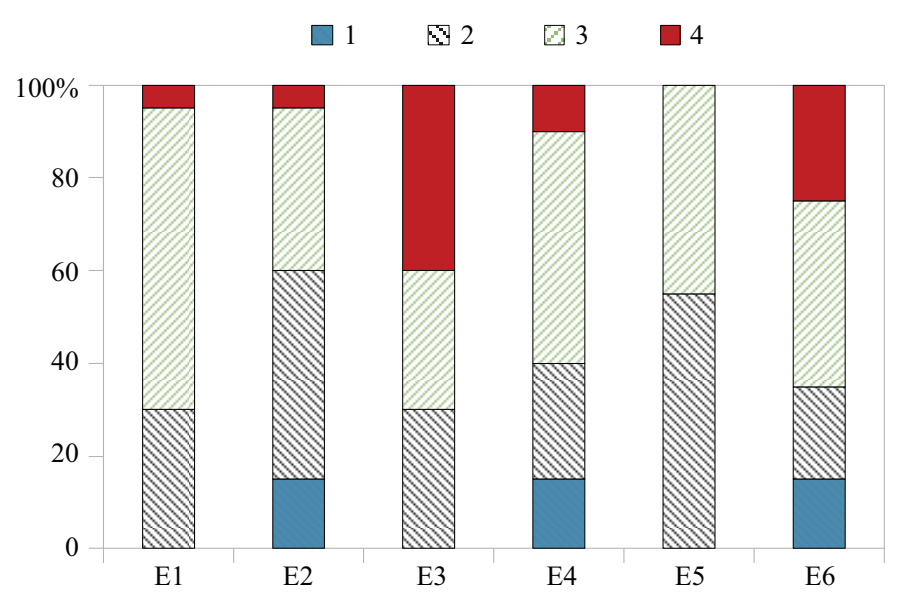

Sources: Authors' assessment.

Accessibility, timeliness, and a fixed timetable of publication convey a stronger signal on the commitment of the issuing authority to conduct regular financial surveillance and to communicate its assessment of financial stability to the public (E2, E4 and E6). All countries except for three have up-to-date webpages dedicated to FSRs under the central bank's or the regulatory agency's website. However, only 11 countries have a regular publication schedule; five countries have an irregular publication schedule or frequency of issues; and in three more, publications are either significantly delayed or have been discontinued. Only Brazil notifies the actual and regular publication dates on its webpage. None of the countries announces future publication dates or a calendar of publication dates. About one third of FSRs are published more than 6 months after the cut-off dates, when the information therein is already outdated. However, four (Argentina, Chile, Colombia and Mexico) countries issue their reports within three months.

The overall communication strategy for the FSR could be significantly improved. Only a few countries (e.g. Chile and Colombia) provide direct access to the underlying data and posts videos and presentation slides (e.g. Trinidad and Tobago) or an audio presentation (Barbados) on their webpages. There is also little evidence of joint communication strategies around financial stability issues even though oversight of the financial sector was shared across different agencies.

22 For instance, Brazil's report has a box on the impact of political uncertainty on real sector and its spillover to the financial sector; Peru's has one on the reduction of financial dollarization and its effect on bank solvency; Jamaica's one on de-risking and concentration risk; and Trinidad and Tobago's has one on household indebtedness and cross-border linkages 


\subsection{Does the Macroeconomic Context Matter for Quality?}

Given the FSR assessment, is there a connection between the quality of the reports and the country's underlying macroeconomic situation? A look at the correlation between the overall composite score assessed in this study and the specific characteristics of the economy of the country where the report is issued highlight some interesting patterns. It should be emphasized that a high correlation, in and of itself, does not imply the existence of a causal link and, when a link is present, does not provide an indication of the direction of the link. Correlation could stem from a common factor that influences both variables, or - especially in a small sample - could be a "spurious" result of a purely random process that does not reflect any significant underlying relationship. ${ }^{23}$ Nevertheless, correlations can provide a useful, if imperfect, signal of what macroeconomic context could be more conducive to producing high quality and candid assessments of financial stability issues.

Bearing these caveats in mind, we observe the following patterns:

- The best reports tend to be issued by the largest and more advanced economies. The overall composite score is positively correlated with the issuing country's GDP, population, and if offshore centers are excluded - per-capita income; this correlation is not driven by the three largest economies (Argentina, Brazil, and Mexico), and is actually stronger when these countries are excluded from the sample. This correlation may reflect both a larger availability of resources to produce high-quality reports in larger economies, and a stronger demand for accurate and timely financial sector information (Figures 11 and 12), as larger economies have more at stake in preserving financial stability.

Figure 11

Comprehensive Score by GDP (2015) (score scale from 1 to 4; 4 = full compliance)

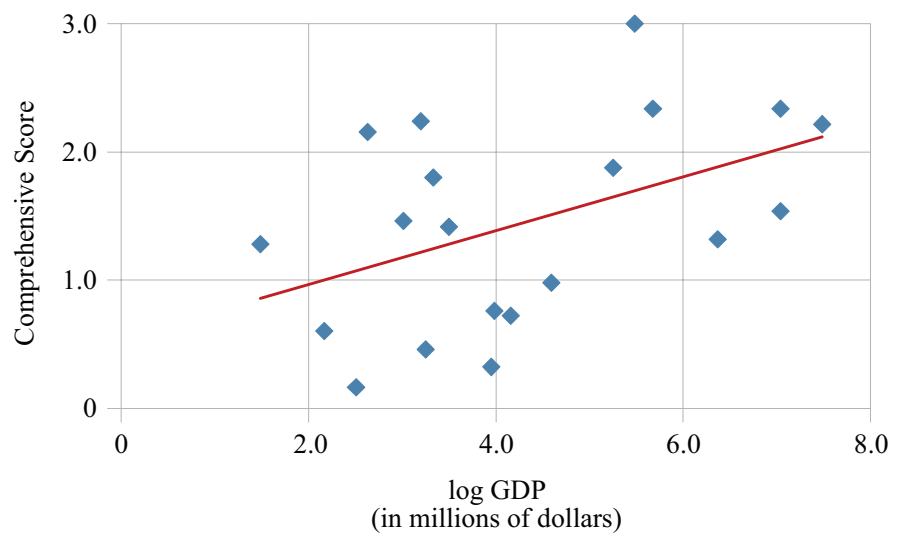

Sources: WEO, April 2016; and authors' calculations.

23 In the limiting case of a sample with only two observations, for instance, the statistical measure of the correlation between any pair of variables is always equal to 1 even when the variables are stochastically independent. 
Figure 12

Comprehensive Score by GDP per Capita (2015) (score scale from 1 to 4 ; 4 = full compliance)

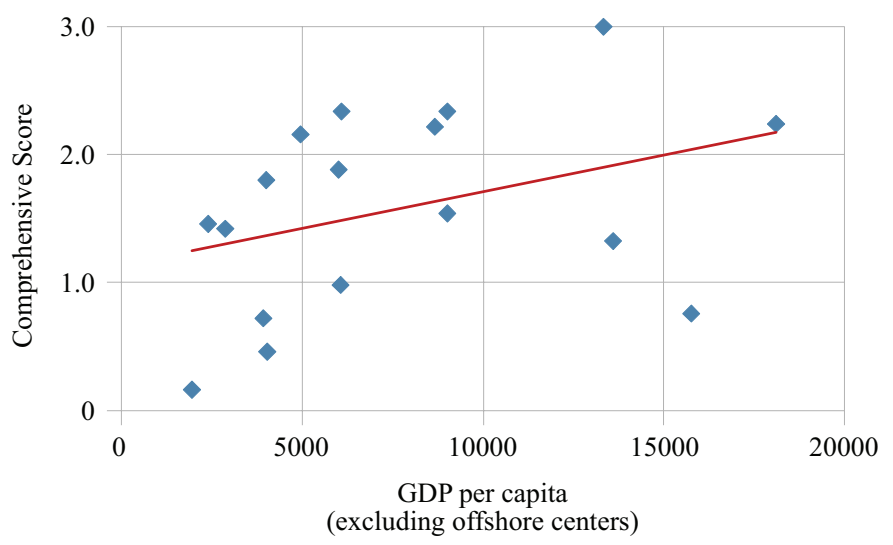

Sources: WEO, April 2016; and authors' calculations.

- The best reports are also issued by countries that have a sizable financial sector (Figure 13). Reports issued by these countries tend to have a more comprehensive coverage of issues (Element C), make greater use of both aggregate and individual bank data, and more sophisticated stress tests with fuller explanations of the underlying assumptions (Element D); and have a more effective structure (Element E).

\section{Figure 13}

Comprehensive Score by Size of the Financial Sector (2015) (score scale from 1 to $4 ; 4=$ full compliance)

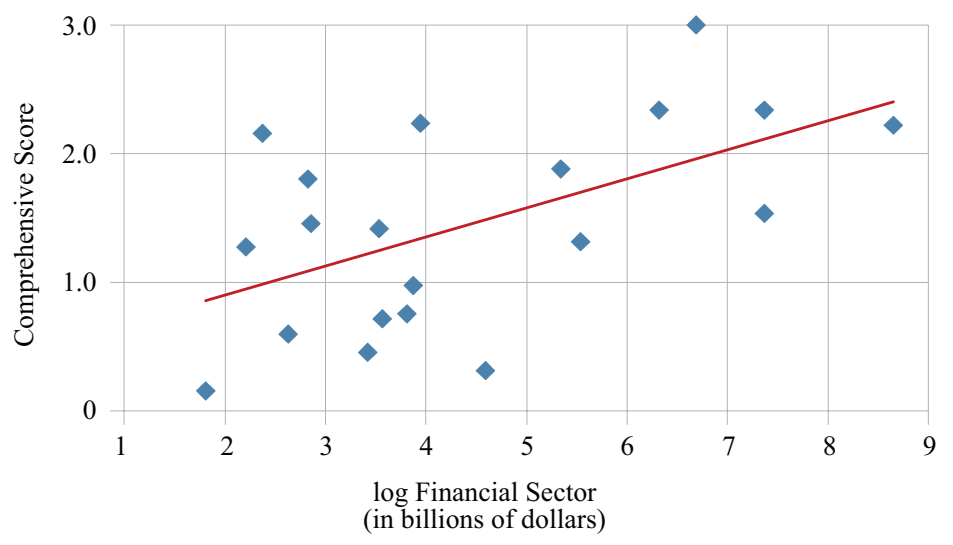

Sources: WEO, April 2016; and authors' calculations.

- Reports issued by central banks tend to be better than those issued by other supervisory authorities, particularly for countries that have floating exchange rates or an inflation targeting framework (Figures 14 and 15). They are more likely to declare their aims and accountability and provide a definition of financial stability within a more effective overall report structure. They are also more candid in their risk assessment and take a systemic view of the financial system. This is because the central banks are usually empowered with an independent mandate to preserve price and exchange rate stability, and in some cases, with an explicit mandate to preserve financial stability. They are therefore held accountable for achieving these objectives, and as a result, more likely to be given access to analytical resources and can justifiably devote a higher proportion of the resources to collecting high-frequency market data and interpreting them, conduct stress tests to monitor emerging threats to the financial system, and consider corrective actions. 
Figure 14

Score by Exchange Rate Regime (score scale from 1 to $4 ; 4$ = full compliance)

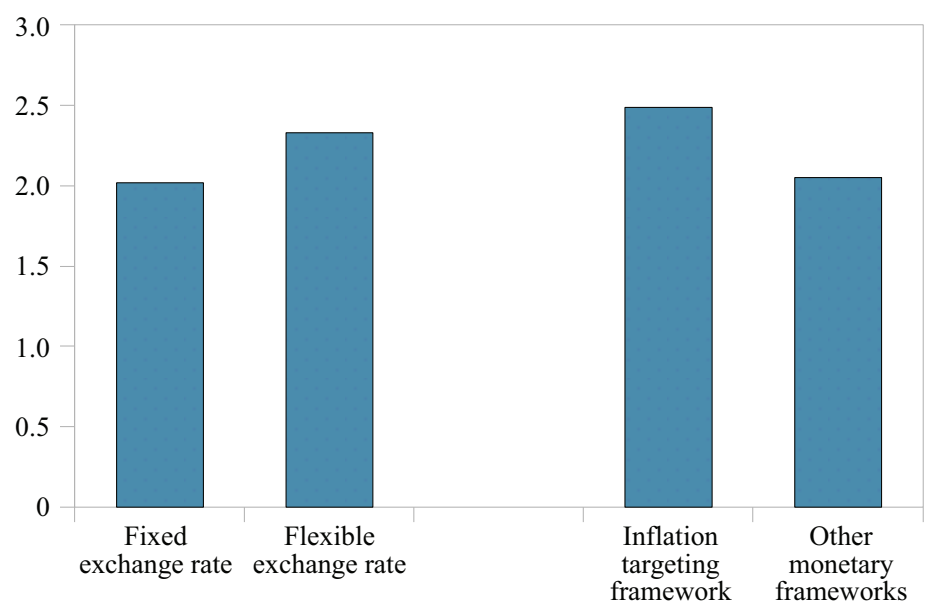

Source: Authors' assessment

\section{Figure 15}

Score by Authoring Institution (score scale from 1 to $4 ; 4=$ full compliance)

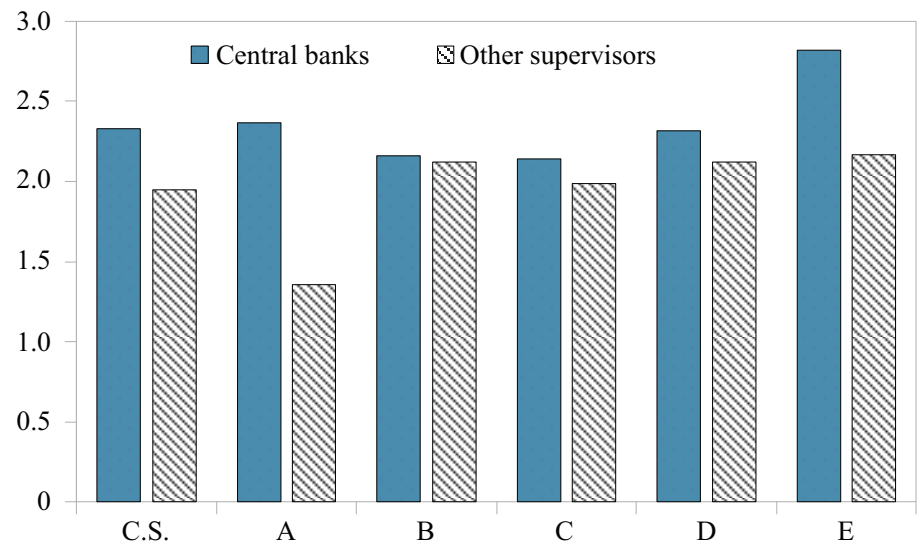

Source: Authors' assessment

- Reports issued by the three offshore centers or dollarized economies do not score as well (Figure 16). There are several possible explanations for this. For one, although in offshore centers the size of the financial sector is large relative to the domestic economy, most of it is "ring-fenced" and has little impact on the domestic financial system. ${ }^{24}$ In dollarized economies, the central bank has no independent monetary policy responsibility, and tends to become a think tank that is less involved in day-to-day surveillance, which could adversely affect its capacity to analyze potential risks, especially if the relationship with the supervisor is not strong.

24 In Panama, for example, offshore (international licensed) banks are not allowed to receive deposits and lend to residents. In addition, offshore banks can conduct interbank transactions, but the scope of such transactions is very limited. Overall, only 1.3 percent of their assets are held in Panama and domestic liabilities represent only 0.3 percent of total offshore banks' liabilities. See Hadzi-Vaskov (2016). 
Figure 16

Score by Dollarization (score scale from 1 to $4 ; 4$ = full compliance)

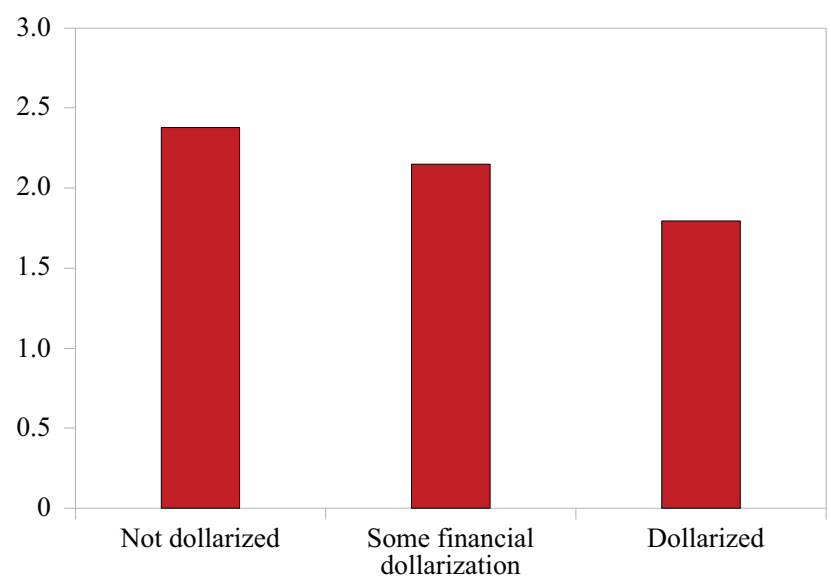

Source: Authors' assessment

- Finally, the best reports tend to be issued by countries that have a higher stock of government debt and higher public expenditure and revenue relative to the size of the economy (Figure 17). ${ }^{25}$ This outcome possibly reflects a stronger motivation to provide credible assessments of financial sector health to investors in order to maintain investor confidence and keep a lid on the cost of refinancing the debt.

Figure 17

Expenditure and Public Debt (2015) (score scale from 1 to $4 ; 4=$ full compliance)

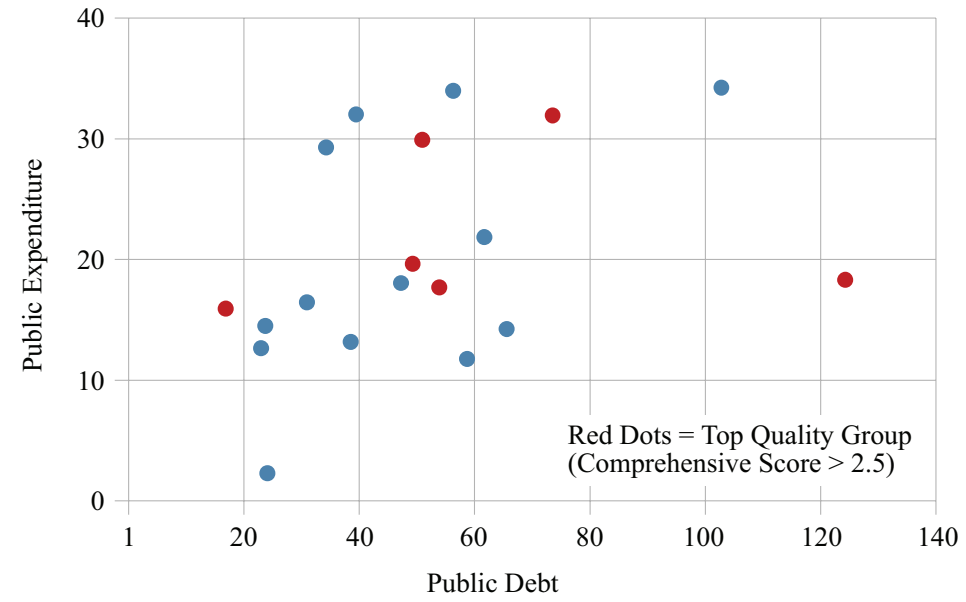

Sources: WEO (Spring 2016); and authors' assessment.

\section{CONCLUSIONS}

This study shows that there is still considerable room for improvement in the quality of FSRs produced in Latin America and the Caribbean. Using the methodology applied by Cihak (2006) and Cihak et al. (2012), this study reviewed the quality of 20 FSRs published by 19 Latin American countries that account for 92 percent of the region's population and GDP. While there is significant heterogeneity in quality across countries, no report complies fully with the established

25 Of the 7 countries with public debt above 49 percent of GDP and public expenditure above 28 percent, only three did not issue reports in the top-quality group; by comparison, of the 12 countries that do not meet these criteria only one - Chile - issued a report in the top-quality group. 
criteria used in this assessment. There is thus significant scope for improving the effectiveness of the region's FSRs as an instrument of surveillance and communication.

Countries with a larger economy and financial sector, and where central banks are the issuing authority, appear, on average, to produce better reports. These results are not surprising, since larger countries should have both larger resources and stronger incentives to produce reports of comparatively good quality. Countries with flexible exchange rates and an inflation targeting framework also produce reports that are, on average, of better quality, possibly reflecting the higher sophistication and capacity associated with these policy regimes, as well as a greater need to keep the public regularly informed. Central banks appear, on average, to produce better reports than other supervisory agencies, possibly reflecting an advantage in terms of independence and mandate, and the synergy from taking a systemic view of both macroeconomic and financial developments. Based on this evidence, there clearly is a role for central banks in producing FSRs, but greater collaboration, including joint publications, with other macroprudential authorities would enhance the credibility of the financial sector assessment and the communication of financial stability risks, particularly during periods of crisis. Greater cooperation between the central bank and other agencies is particularly relevant in countries where there is a shared financial stability or macroprudential mandate

While the areas for improvement vary across countries, some gains can be obtained comparatively rapidly and at low cost. For instance, it would be relatively simple to ensure that all reports include an explicit statement of aims and a definition of financial stability, that the data are made available on the webpage, and that the publication schedule is announced clearly in advance. Explaining and justifying the methodology and assumptions or improving the structure and organization of the reports around specific themes would require more investment but it should be manageable and not too demanding in terms of resources.

Other more substantive improvements to the content of the report will require much more effort. For instance, covering all systemically important areas of the financial system, adopting a forward-looking perspective, computing stress tests with the support of satellite econometric models, and implementing an effective, full-fledged communication strategy will require higher investment in terms of resources and analytical capacity.

At the end of the day, strengthening the quality of the reports will require political resolve and a strong commitment to provide unbiased and transparent communication. These conditions are usually met when the issuing authority has a clear mandate for financial stability, access to data and resources, and operational independence from the government. Most notably, providing a candid and timely assessment of all risks, actual and potential, requires confidence on the part of the authorities, that the benefits of honest communication with the general public outweigh the risks that come with discussing sensitive information, especially in times of stress. It also involves a preparedness to be held accountable for the policy actions the authorities take to mitigate risks, respond to shocks, and enhance long-term resilience. Such accountability is an essential component of a robust and resilient financial system.

\section{Disclaimer}

The views expressed in this paper are those of the authors and do not necessarily represent the views of the IMF, its Executive Board, or IMF management. 


\section{References}

Borio C., Drehmann M. (2009) Towards and Operational Framework for Financial Stability: 'Fuzzy' Measurement and Its Consequences. BIS Working Papers, No 284.

Born B., Ehrmann M., Fratzscher M. (2014) Central Bank Communication on Financial Stability. Economic Journal Vol 124, pp. 701-734.

Centre for Money and Finance (2016) Caribbean Regional Financial Stability Report 2015, University of the West Indies.

Cihak M. (2006) How Do Central Banks Write on Financial Stability? IMF Working Paper No WP/06/163.

Cihak, M., Munoz S., Sharifuddin S. T., Tinchev K. (2012) Financial Stability Reports: What Are They Good for? IMF Working Paper No WP/12/1.

Correa, R., Garud K., Londono J.M., Mislang N. (2017) Sentiment in Central Banks' Financial Stability Reports. International Finance Discussion Papers No. 1203.

Hadzi-Vaskov, M. (2016) Economic Effects of Panama's Offshore Banking Sector. Panama-Selected Issues. IMF Country Reports No. 16/338, pp. 36-42.

McKinsey \& Co. (2009) Global capital markets: Entering a new era. McKinsey Global Institute Report, September 2009.

Osterloo, S., de Haan J., Jong-A-Pin R. (2007) Financial Stability Reviews: A First Empirical Analysis. Journal of Financial Stability Vol. 2, pp. 337-355.

Wilkinson, J., Spong K., Christensson J. (2010) Financial Stability Reports: How Useful During a Financial Crisis? Federal Reserve Bank of Kansas City Economic Review. 


\section{APPENDIX}

\section{Appendix Table 1}

Areas of Assessment and their Component Weights

\begin{tabular}{|c|c|c|}
\hline & & Weight \\
\hline A. $A$ & ims. Objectives and Reasons & 0.21 \\
\hline A1 & The aims of the report should be clearly indicated & 0.03 \\
\hline & The definition of financial stability should be clearly indicated & 0.03 \\
\hline & $\begin{array}{l}\text { The definition of financial stability should be a standard part of the report, presented consistently } \\
\text { across reports }\end{array}$ & 0.03 \\
\hline & The statements of aims should be a standard part of the report, presented consistently across reports & 0.03 \\
\hline & $\begin{array}{l}\text { The definition of financial stability should be cover both the absence of a crisis and the resilience to } \\
\text { a crisis }\end{array}$ & 0.03 \\
\hline & Financial stability should be defined both in general terms and in operational terms & 0.03 \\
\hline & The aims of the report should be comprehensive & 0.03 \\
\hline B. $\mathrm{C}$ & Derall assessment & 0.20 \\
\hline & The overall assessment should be presented clearly and in candid terms & 0.05 \\
\hline & The overall assessment should be linked to the remainder of the FSR & 0.05 \\
\hline & $\begin{array}{l}\text { There should be a clear link between the assessments over time, making it clear where the main } \\
\text { changes took place }\end{array}$ & 0.05 \\
\hline & The overall assessment should cover the key topics & 0.05 \\
\hline C. $\mathbf{C}$ & Coverage of issues & 0.17 \\
\hline & The report should clearly identify the main macro-relevant stability issues & 0.05 \\
\hline & The coverage of issues should be consistent across the reports & 0.06 \\
\hline & The coverage of the financial system should be sufficiently comprehensive & 0.06 \\
\hline D. I & Data, assumptions, and tools & 0.30 \\
\hline & It should be clear what data are used to arrive at the results presented in the reports & 0.05 \\
\hline & It should be clear what assumptions are used to arrive at the results presented in the reports & 0.05 \\
\hline & It should be clear what methodological tools are used to arrive at the results presented in the reports & 0.05 \\
\hline & The results should be presented in a consistent way across reports & 0.05 \\
\hline & The report should use available data, including those on individual institutions & 0.05 \\
\hline & The report should use the available tools & 0.05 \\
\hline E. $S$ & tructure and other features & 0.12 \\
\hline & The structure of the report should be easy to follow & 0.02 \\
\hline & $\begin{array}{l}\text { Other features of the report (e.g., its length, frequency, timing, public availability and links to other } \\
\text { central banks reports) should be designed to support its clarity }\end{array}$ & 0.02 \\
\hline E3 & The structure of the report should be consistent across time to make it easier to follow for repeat users & 0.02 \\
\hline E4 & The other features of the report should be designed to support its consistency & 0.02 \\
\hline & The structure of the report should allow coverage of the key topics & 0.02 \\
\hline E6 & The other features of the report should be designed to supports its coverage & 0.02 \\
\hline
\end{tabular}

Sources: Cihak et al. (2012) 
Appendix Table 2

Rating Criteria by Category

\begin{tabular}{cllll}
\hline \hline Ratings & 1 & 2 & 3 & 4 \\
\hline
\end{tabular}

\section{A. Aims, Objectives and Reasons}

\begin{tabular}{|c|c|c|c|c|c|}
\hline A1 & $\begin{array}{l}\text { The aims of the } \\
\text { report should be } \\
\text { clearly indicated. }\end{array}$ & $\begin{array}{l}\text { No aims are } \\
\text { indicated in the } \\
\text { report. Stating the } \\
\text { aims of the authoring } \\
\text { agency (i.e., central } \\
\text { bank/regulator) is not } \\
\text { sufficient. }\end{array}$ & $\begin{array}{l}\text { Aims are not } \\
\text { included in } \\
\text { the report, but } \\
\text { stated elsewhere } \\
\text { (e.g., FSR website). }\end{array}$ & $\begin{array}{l}\text { Aims are stated } \\
\text { in the report, but } \\
\text { expressed in general } \\
\text { terms and not } \\
\text { specific to financial } \\
\text { stability. }\end{array}$ & $\begin{array}{l}\text { Aims are clearly } \\
\text { stated as the aim of } \\
\text { the report, and makes } \\
\text { specific references to } \\
\text { the financial stability. }\end{array}$ \\
\hline $\mathrm{A} 2$ & $\begin{array}{l}\text { The definition of } \\
\text { financial stability } \\
\text { should be clearly } \\
\text { indicated. }\end{array}$ & $\begin{array}{l}\text { No definition of } \\
\text { financial stability is } \\
\text { provided. }\end{array}$ & $\begin{array}{l}\text { Definition is not } \\
\text { included in the } \\
\text { report, but stated } \\
\text { elsewhere (e.g., } \\
\text { FSR website). }\end{array}$ & $\begin{array}{l}\text { Definition is stated } \\
\text { in the report, but it } \\
\text { is not upfront and } \\
\text { buried in a glossary } \\
\text { or footnote. }\end{array}$ & $\begin{array}{l}\text { Definition is clearly } \\
\text { stated in the report. }\end{array}$ \\
\hline A3 & $\begin{array}{l}\text { The definition } \\
\text { of financial } \\
\text { stability should } \\
\text { be a standard } \\
\text { part of the } \\
\text { report, presented } \\
\text { consistently } \\
\text { across reports. }\end{array}$ & $\begin{array}{l}\text { No definition of } \\
\text { financial stability } \\
\text { provided. }\end{array}$ & $\begin{array}{l}\text { Definition } \\
\text { not included } \\
\text { in the report, } \\
\text { but elsewhere } \\
\text { (e.g., FSR website). }\end{array}$ & $\begin{array}{l}\text { Definitions not } \\
\text { consistently } \\
\text { included in the } \\
\text { reports. }\end{array}$ & $\begin{array}{l}\text { Definitions always } \\
\text { included in the report. }\end{array}$ \\
\hline
\end{tabular}

A4 The statement of aims should be a standard part of the report, presented consistently across reports.

Aims not included in Aims not included the report. in the report, but elsewhere (e.g., FSR website).
Aims not consistently included in the reports.
Aims always included in the report.
A5 The definition of No definition of financial stability financial stability should cover both the absence of a crisis and resilience to a crisis. provided.

\section{Definition in the} report covers neither the absence of nor resilience to a crisis (or shocks) OR Definition not included in the report, but elsewhere (e.g., FSR website).
A6 Financial No definition of stability should be defined both in general terms and in operational terms. provided. financial stability

Definition in the report, but only in general terms OR Definition not included in the report, but elsewhere (e.g., FSR website).
Definition makes reference to either absence of or resilience to a crisis. This includes reference to the system's ability to withstand shocks.
Definition covers both absence of crisis and resilience to a crisis (or shock).
Definition includes both general and operational aspects, and operational definition includes either criteria on resilience to shocks or on the absence of crisis (i.e., clear criteria when to declare crisis).
Definition covers both general and operational (e.g., well-capitalized, liquid, efficient functioning of payment system, absence of wide-spread contagion, LOLR, strong regulatory framework) aspects. 
A7 The aims of the report should be comprehensive.
Aims not included in Aims in the report the report.

do not include any of the four recommended aims (see rating of 4) OR Some comprehensive aims included, but only on website.
Aims include at least one of the four recommended aims (see rating of 4 ).
Aims include all four of the following aims: (i) informing stakeholders of potential financial risks, (ii) encouraging debate, (iii) serving as an accountability instrument, and (iv) helping to provide information to be used for risk assessments.

\section{B. Overall assessment}

B1 The overall assessment should be presented clearly and in candid terms.

B2 The overall assessment should be linked to the remainder of the FSR.

\author{
No executive \\ summary (or \\ equivalent section).

.

\section{No executive} summary (or
equivalent section). summary (or
equivalent section).

\section{Executive summary (or its equivalent) provides some assessment of risks, but is mainly descriptive and backward looking.}

Executive summary provides clear overview of risks (e.g., heat maps), but it is less candid and the readers have to read between the lines.
Executive summary provides clear and candid assessment, highlighting risks and gaps.

\section{Executive summary Executive summary Overall assessment summarizes the covers findings rest of the report, of the analysis in but does not link the report, and together different contains some chapters and mostly forward-looking backward looking. components. \\ puts together the various pieces of analysis, and the picture it presents is comprehensive and forward looking.}

\section{Coverage centers on Overall assessment} backward-looking mentions the didevelopments in rection of changes indicators, and in the risk assesslimited references to changes in forward-looking risk assessments.

B4 The overall should cover the key topics. main changes took place. assessment

\section{No or limited} indicators or assessments over assessment over time.

No or limited discussion of risks.
Overall assessment Overall assessment covers key topic and risks often in the context of key indicators and stress tests, but is mostly descriptive and backward looking, and not focused on potential risks.

covers key topics including macrofinancial developments and their implications on financial stability, and discussions of specific risks. ment from previous reports, but does not explain why and transmission channels. how it changed.
Overall assessment explicitly explains why and how the main risks and exposures have evolved since the last FSR, making clear the (t) Overall assessment discusses all significant risks and exposures in the assessment, including potential and politically sensitive risks, and full discussion of vulnerabilities.

\section{Issues}

C1 The report Macroeconomic should clearly risks identified, identify the main but important macro-relevant financial stability stability issues. risks omitted and macroeconomic and financial analyses not integrated.
Various financial stability risks identified, but no assessment of their relative importance and implications.

Macro and financial risks are not well integrated.
Various risks identi- Risks with wider fied as having sys- $\quad$ systemic impact temic impact, but highlighted and no in-depth analysis covered both in overall in terms of rela- assessment and in tive importance and some depth. Significant implications. Some macro financial integration of mac- integration. rofinancial risks. 
C2 The coverage of issues should be consistent across the reports.

Coverage not consistent over time and changes not explained.
Coverage broadly consistent, but key risks not identified OR Changes to the worse and changes not explained.

C3 The coverage of the financial system should be sufficiently comprehensive.
Report covers only banking sector.
Banks and some of the other financial players (e.g., nonbanks, payment system, borrowers) covered, but not in depth.
Coverage is consistent, special risks are highlighted.

Banks, non-banks and other financial players (e.g., SIFIs, shadow banks) covered, and analyzed them in greater depth.
Consistent Coverage, and special risks highlighted. Follows up on previously-raised risks and explanation of newly-added risks.

Banking system covered in depth, non-banks, payment systems, and other issues (e.g. borrowers, regulatory changes) also analyzed. Any lack of coverage is explained and justified.

\section{Data, Assumptions, and Tools} what data are used to arrive at the results presented in the report. sources not specified, types of information and underlying data not available on the website.
Two of the three (see ranking of 1) provided. (see ranking of 1) provided.
Data cut-off date highly visible, sources specified at the bottom of the tables and charts, and underlying data made available as electronic link on the website.

Report discusses, explains, and justifies the assumptions. clear what assumptions are being used to arrive at the results presented in the report.

D3 It should be clear what methodological tools are used to arrive at the results presented in the report.

D4 The results should be presented in a consistent way across reports.
Assumptions for stress tests or any other quantitative analyses not provided.
Assumptions are provided, but are not explained or justified.
Report discusses assumptions and provides some justifications and explanations.

No stress test or other General explanation Methodology is forward-looking risk of methodology that explained, but not assessment analysis lacks detail. OR The methodology is not explained. in full OR Full explanation, but the approach does not seem suitable for the risk that is being assessed.

\author{
Clear and detailed \\ explanation of \\ an appropriate \\ methodology.
}
Analyses and results, either in
Analyses and results, tables or text, are presented in a mostly consistent way across reports, facilitating comparison. Assumptions are mostly consistent. either in tables or text, are presented in a consistent and comparable way across reports, and assumptions are consistent. The stress test results are explicitly compared with those in the previous report. either in tables or text, are presented in a very different way across reports OR Lack of analyses and results that could be compared across reports.

Analyses and results, either in tables or text, are presented in a similar structure across reports, but differences in presentation render the comparison difficult. 


\begin{tabular}{|c|c|c|c|c|c|}
\hline D5 & $\begin{array}{l}\text { The report } \\
\text { should use } \\
\text { available data, } \\
\text { including those } \\
\text { on individual } \\
\text { institutions. }\end{array}$ & $\begin{array}{l}\text { Only aggregate } \\
\text { results shown. }\end{array}$ & $\begin{array}{l}\text { Mostly aggregate } \\
\text { results, with some } \\
\text { breakdown by types } \\
\text { of institution/range. }\end{array}$ & $\begin{array}{l}\text { More granular } \\
\text { results (e.g., } \\
\text { range, reference to } \\
\text { individual/types } \\
\text { of institutions); } \\
\text { analysis is based } \\
\text { on both individual } \\
\text { and aggregate data. }\end{array}$ & $\begin{array}{l}\text { Both individual and } \\
\text { aggregate data used } \\
\text { effectively, and both } \\
\text { individual and systemic } \\
\text { risks analyzed. } \\
\text { Important missing } \\
\text { data are mentioned. }\end{array}$ \\
\hline D6 & $\begin{array}{l}\text { The report } \\
\text { should use the } \\
\text { available tools. }\end{array}$ & $\begin{array}{l}\text { Assessment relies } \\
\text { mostly on basic } \\
\text { financial indicators } \\
\text { (e.g., changes in } \\
\text { credits, interest rates, } \\
\text { and bank balance } \\
\text { sheets). }\end{array}$ & $\begin{array}{l}\text { Mostly FSIs and } \\
\text { simple quantitative } \\
\text { tools presented; } \\
\text { no or rudimentary } \\
\text { stress tests. }\end{array}$ & $\begin{array}{l}\text { Quantitative tools } \\
\text { used (e.g., FSIs } \\
\text { and stress tests), } \\
\text { but only limited } \\
\text { qualitative tools } \\
\text { (e.g., regulatory } \\
\text { framework, } \\
\text { qualitative } \\
\text { supervisory } \\
\text { information). }\end{array}$ & $\begin{array}{l}\text { Combination of } \\
\text { available quantitative } \\
\text { and qualitative tools } \\
\text { to allow for a forward- } \\
\text { looking assessment } \\
\text { of risk. }\end{array}$ \\
\hline
\end{tabular}

\section{E. Structure and other features}

E1 The structure of the report should be easy to follow.
No underlying logic or theme to the structure.

\section{Structure is simple,} or not sufficient to cover full range of issues. No unifying themes, and in some cases no executive summary.

No dedicated webpage for FSRs.

of the report (e.g., its length, frequency, timing, public availability, and links to other central bank reports) should be designed to support its clarity.
Dedicated webpage

for FSRs with current and past reports, but either (i) hard to find, or (ii) not accompanied by any of the following: communication strategy (e.g., press release, presentations, videos), links to other relevant, specific publications, official publication date, and underlying data.

Structure changed Structure largely without explanation consistent; any OR Structure changes are for broadly consistent, the better. but has become less comprehensive.
Report has an integrated structure with unifying themes that is well explained.

coverage. No unifying theme, but structure allows upfront summary of key issues.

Dedicated webpage Dedicated for FSRs with webpage specifies current and past reports. The webpage has one of the following: communication strategy, links to other relevant, specific publications, official publication date, and underlying data. communication strategy, underlying data, and specific links to other relevant publications.
E3 The structure of Structure not the report should consistent across be consistent past reports. across time to make it easier to follow for repeat users.
Consistent structure across reports that clearly distinguishes core analysis from special topics. 


\begin{tabular}{|c|c|c|c|c|c|}
\hline E4 & $\begin{array}{l}\text { The other } \\
\text { features of the } \\
\text { report should } \\
\text { be designed } \\
\text { to support its } \\
\text { consistency. }\end{array}$ & $\begin{array}{l}\text { No predictable } \\
\text { timetable; some } \\
\text { of the past reports } \\
\text { are missing/no } \\
\text { publication in some } \\
\text { years. }\end{array}$ & $\begin{array}{l}\text { No clear timetable; } \\
\text { publication appears } \\
\text { somewhat irregular; } \\
\text { past reports are } \\
\text { available. }\end{array}$ & $\begin{array}{l}\text { No clear timetable; } \\
\text { publication dates } \\
\text { not specified, but } \\
\text { appear regular; } \\
\text { past reports are } \\
\text { available. }\end{array}$ & $\begin{array}{l}\text { Well-known, regular } \\
\text { and predictable } \\
\text { timetable; past reports } \\
\text { are available. }\end{array}$ \\
\hline E5 & $\begin{array}{l}\text { The structure of } \\
\text { the report should } \\
\text { allow coverage } \\
\text { of the key topics. }\end{array}$ & $\begin{array}{l}\text { There is no logical } \\
\text { structure to the } \\
\text { report. }\end{array}$ & $\begin{array}{l}\text { Logical structure } \\
\text { that allows coverage } \\
\text { of key topics, but } \\
\text { largely follows } \\
\text { silo approach } \\
\text { and sections } \\
\text { (e.g., executive } \\
\text { summary, } \\
\text { conclusion, boxes) } \\
\text { that allow to bring } \\
\text { together themes not } \\
\text { utilized well. }\end{array}$ & $\begin{array}{l}\text { Logical structure } \\
\text { that allows coverage } \\
\text { of key topics. } \\
\text { Largely follows silo } \\
\text { approach, but boxes } \\
\text { and annexes allow } \\
\text { for discussions of } \\
\text { specific themes, and } \\
\text { there are sections } \\
\text { (e.g., executive } \\
\text { summary, } \\
\text { conclusion, boxes) } \\
\text { attempting to } \\
\text { bring together } \\
\text { key messages that } \\
\text { emerges from } \\
\text { subsectors. }\end{array}$ & $\begin{array}{l}\text { Structure of the report } \\
\text { allows for presentation } \\
\text { of cross-cutting topics, } \\
\text { integrating various } \\
\text { sub-sectors. }\end{array}$ \\
\hline E6 & $\begin{array}{l}\text { The other } \\
\text { features of the } \\
\text { report should } \\
\text { be designed } \\
\text { to support its } \\
\text { coverage. }\end{array}$ & $\begin{array}{l}\text { Report outdated } \\
\text { and has not been } \\
\text { updated for more } \\
\text { than } 12 \text { months. }\end{array}$ & $\begin{array}{l}\text { Published within } \\
12 \text { months of the } \\
\text { data cutoff date. }\end{array}$ & $\begin{array}{l}\text { Published within } \\
6 \text { months of the } \\
\text { data cutoff date. }\end{array}$ & $\begin{array}{l}\text { Published within } \\
3 \text { months of the } \\
\text { data cutoff date. }\end{array}$ \\
\hline
\end{tabular}


Appendix Table 3

List of the FSRs Reviewed in this Study

\begin{tabular}{|c|c|c|c|c|c|}
\hline Country & Issuing Authority & Name of the Report & $\begin{array}{c}\text { First } \\
\text { Publication } \\
\text { Date }\end{array}$ & $\begin{array}{l}\text { Latest } \\
\text { Publication } \\
\text { as of July } \\
2016\end{array}$ & Frequency \\
\hline Argentina & $\begin{array}{l}\text { Banco Central de la } \\
\text { Republica Argentina }\end{array}$ & Informe de Estabilidad Financiera & 2004 & July-16 & 6 months \\
\hline Barbados & $\begin{array}{l}\text { Central Bank of } \\
\text { Barbados }\end{array}$ & Financial Stability Report & 2011 & Feb-16 & $\begin{array}{l}\text { Annual, mid- } \\
\text { year update }\end{array}$ \\
\hline Bolivia & Banco Central de Bolivia & Informe de Estabilidad Financiera & 2006 & Apr-16 & 6 months \\
\hline Brazil & Banco Central do Brasil & Relatório de Estabilidade Financeira & 2002 & Apr-16 & 6 months \\
\hline Chile & Banco Cenral de Chile & Informe de Estabilidad Financiera & 2004 & June-16 & 6 months \\
\hline Colombia & $\begin{array}{l}\text { Banco de la República } \\
\text { Colombia }\end{array}$ & Reporte de Estabilidad Financiera & 2002 & Mar-16 & 6 months \\
\hline Ecuador & $\begin{array}{l}\text { Superintendencia de } \\
\text { Bancos del Ecuador }\end{array}$ & Reporte de Estabilidad Financiera & 2013 & June-14 & Annual \\
\hline $\begin{array}{l}\text { El } \\
\text { Salvador }\end{array}$ & $\begin{array}{l}\text { Banco Central de } \\
\text { Reserva de El Salvador }\end{array}$ & Informe de Estabilidad Financiera & 2007 & June-16 & 6 months \\
\hline Guatemala & $\begin{array}{l}\text { Superintendencia de } \\
\text { Bancos Guatemala }\end{array}$ & Informe de Estabilidad Financiera & 2007 & June-12 & Annual \\
\hline Honduras & $\begin{array}{l}\text { Banco Central de } \\
\text { Honduras, Subgerencia } \\
\text { de Estudios Económicos }\end{array}$ & Informe de Estabilidad Financiera & 2012 & 2016 & 6 months \\
\hline Jamaica & Bank of Jamaica & Financial Stability Report & 2005 & 2015 & Annual \\
\hline Mexico & Banco de México & Reporte sobre el Sistema Financiero & 2011 & Mar-16 & Annual \\
\hline Mexico & $\begin{array}{l}\text { Consejo de Estabilidad } \\
\text { del Sistema Financiero }\end{array}$ & $\begin{array}{l}\text { Informe anual sobre el estado que } \\
\text { guarda la estabilidad del sistema } \\
\text { financiero en México y sobre las } \\
\text { actividades realizadas por el Consejo } \\
\text { de Estabilidad del Sistema Financiero }\end{array}$ & 2006 & Nov-15 & Annual \\
\hline Nicaragua & $\begin{array}{l}\text { Banco Central de } \\
\text { Nicaragua }\end{array}$ & Informe de Estabilidad Financiera & 2013 & Sep-14 & 6 months \\
\hline Panama & $\begin{array}{l}\text { Superintendencia de } \\
\text { Bancos de Panamá, } \\
\text { Dirección de Estudios } \\
\text { Financieros }\end{array}$ & Informe de Estabilidad Financiera & 2012 & 2016 & Annual \\
\hline Paraguay & $\begin{array}{l}\text { Banco Central del } \\
\text { Paraguay }\end{array}$ & Informe de Estabilidad Financiera & 2009 & Apr-16 & 6 months \\
\hline Peru & $\begin{array}{l}\text { Banco Central de } \\
\text { Reserva del Perú }\end{array}$ & Reporte de Estabilidad Financiera & 2006 & May-16 & 6 months \\
\hline $\begin{array}{l}\text { The } \\
\text { Bahamas }\end{array}$ & $\begin{array}{l}\text { The Central Bank of the } \\
\text { Bahamas }\end{array}$ & Financial Stability Report & 2012 & Feb-16 & Annual \\
\hline $\begin{array}{l}\text { Trinidad } \\
\text { and Tobago }\end{array}$ & $\begin{array}{l}\text { Central Bank of Trinidad } \\
\text { and Tobago }\end{array}$ & Draft Financial Stability Report & 2008 & Jun-16 & Annual \\
\hline Uruguay & $\begin{array}{l}\text { Banco Central } \\
\text { del Uruguay, } \\
\text { Superintendencia de } \\
\text { Servicios Financieros }\end{array}$ & Reporte del Sistema Financiero & 2010 & Jul-16 & Annual \\
\hline
\end{tabular}

Sources: FSRs; websites of different entities issuing FSRs. 